University of Montana

ScholarWorks at University of Montana

Graduate Student Theses, Dissertations, \&

Professional Papers

1982

\title{
Effect of ACTH on rabbit adrenal microsomal 17a-hydroxylase activity cytochrome P-450 and protein electrophoretic patterns
}

Jon Eric Peterson

The University of Montana

Follow this and additional works at: https://scholarworks.umt.edu/etd

Let us know how access to this document benefits you.

\section{Recommended Citation}

Peterson, Jon Eric, "Effect of ACTH on rabbit adrenal microsomal 17a-hydroxylase activity cytochrome P-450 and protein electrophoretic patterns" (1982). Graduate Student Theses, Dissertations, \& Professional Papers. 7210.

https://scholarworks.umt.edu/etd/7210

This Thesis is brought to you for free and open access by the Graduate School at ScholarWorks at University of Montana. It has been accepted for inclusion in Graduate Student Theses, Dissertations, \& Professional Papers by an authorized administrator of ScholarWorks at University of Montana. For more information, please contact

scholarworks@mso.umt.edu. 


\section{COPYRIGHT ACT OF 1976}

THIS IS AN UNPUBLISHED MANUSCRIPT IN WHICH COPYRIGHT SUBSISTS. ANY FURTHER REPRINTING OF ITS CONTENTS MUST BE APPROVED BY THE AUTHOR.

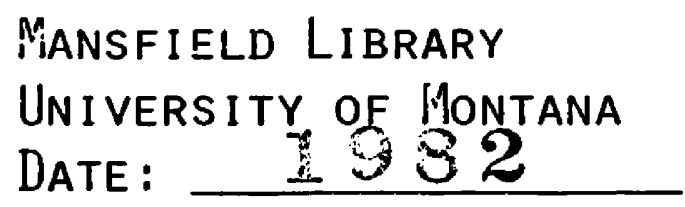





\title{
EFFECT OF ACTH ON RABBIT \\ ADRENAL MICROSOMAL $17 \alpha-H Y D R O X Y L A S E$ \\ ACTIVITY, CYTOCHROME P-450 AND \\ PROTEIN ELECTROPHORETIC PATTERNS
}

\author{
By \\ Jon Eric Peterson \\ B.A. Wartburg College 1977
}

Presented in partial fulfillment of the requirements for the degree of Master of Science

UNIVERSITY OF MONTANA

1982

Approved by:
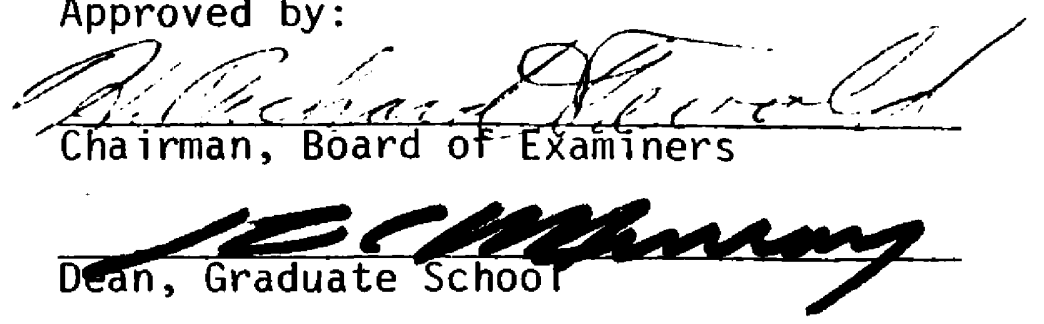

Date $12-6-82$ 
UMI Number: EP38011

All rights reserved

INFORMATION TO ALL USERS

The quality of this reproduction is dependent upon the quality of the copy submitted.

In the unlikely event that the author did not send a complete manuscript and there are missing pages, these will be noted. Also, if material had to be removed, a note will indicate the deletion.

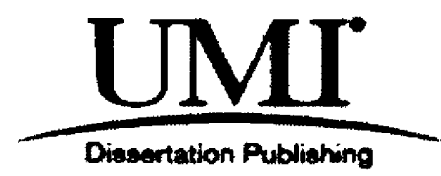

UMI EP38011

Published by ProQuest LLC (2013). Copyright in the Dissertation held by the Author.

Microform Edition () ProQuest LLC.

All rights reserved. This work is protected against unauthorized copying under Title 17, United States Code

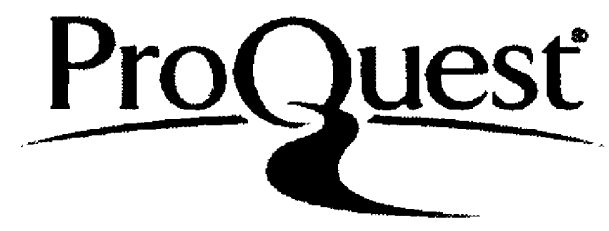

ProQuest LLC.

789 East Eisenhower Parkway

P.O. Box 1346

Ann Arbor, MI 48106 - 1346 
Peterson, Jon E.

Effect of ACTH on Rabbit Adrenal Microsomal 17 $\alpha$-Hydroxylase Activity, Cytochrome P-450 and Protein Electrophoretic Patterns (56 pp.)

Director: Dr. H. Richard Fevold.

The purpose of this study was to determine if an increase of $17 \alpha$-hydroxylation of pregnenolone in rabbit adrenal microsomes, seen with long-term adrenocorticotropic hormone (ACTH) stimulation, was due to a net increase in a specific electrophoretic protein band ascribed to cytochrome P-450, the catalytic center of $17 \alpha$-hydroxylase. Sodium dodecyl sulfate polyacrylamide gel electrophoresis (SDS-PAGE) patterns were obtained from two, four and six day ACTH stimulated rabbit adrenal microsomes. A 53,000 D protein band was found to increase $31.1 \%$ in two day, $27.2 \%$ in four day and $61.0 \%$ in six day ACTH stimulated microsomes as compared to controls. ACTH stimulation was confirmed by $17 \alpha$-hydroxylase activity which was found to be $0.429 \pm 0.040 \mathrm{nmol} / \mathrm{min} / \mathrm{mg}$ for two day, $0.631 \pm 0.120 \mathrm{nmol} / \mathrm{min} / \mathrm{mg}$ for four day and $0.440 \pm$ $0.070 \mathrm{nmol} / \mathrm{min} / \mathrm{mg}$ for six day ACTH stimulated samples. Control values for $17 \alpha$-hydroxylase were $0.078 \pm 0.028$ to $0.115 \pm 0.003$ $\mathrm{nmol} / \mathrm{min} / \mathrm{mg}$. Total content of cytochrome $\mathrm{P}-450$ was found to increase $11 \%$ in two day, $35 \%$ in four day and $90 \%$ in six day ACTH stimulated adrenal microsomes. The specific activity (nmol/ mg protein) of cytochrome P-450 was found to remain nearly the same throughout the stimulation periods. Tetramethylbenzidine staining for heme prosthetic groups on SDS-PAGE gels displayed intense staining at $61,000 \mathrm{D}$ with minor staining at 58,000 D and $53,000 \mathrm{D}$. 


\section{SUMMARY}

The purpose of this investigation was to correlate detectable changes in electrophoretic protein patterns with cytochrome P-450 content and $17 \alpha$-hydroxylase activity in adrenal microsomes from rabbits stimulated with $A C T H$. It was hoped that a linear increase in a specific protein attributed to a cytochrome $\mathrm{P}-450$ responsible for $17 \alpha$-hydroxylase activity would be seen with the duration of multi-day stimulations as compared to controls.

Earlier investigations (56) showed the specific activity of cytochrome P-450 does not increase with long-term ACTH stimulation. Since multiple cytochromes are known to exist in steroidogenic microsomes (32) the preferential increase in a specific cytochrome responsible for $17 \alpha$-hydroxylase may be detected by electrophoresis accompanied by a loss in a different protein band.

An increase in a 53,000 $\mathrm{D}$ band was found to occur, but not in a linear manner and did not parallel 17a-hydroxylase activities or cytochrome P-450 specific activities. The total concentration of cytochrome P-450 was found to increase in a linear manner. A decrease in a specific protein $(57,000$ D) was observed though not reproducible. 
SUBJECT

PAGE

Title Page

i

Abstract

i i

Summary

i i i

Table of Contents

iv

List of Tables

v

List of Illustrations

vi

Acknowl edgements

vi i

Introduction

1

Statement of Problem

13

Materials

Experimental Methods

Results

Discussion

References 


\section{LIST OF TABLES}

TABLE

PAGE

1. Comparison of Body Weights of Control and ACTH -Stimulated Rabbits.

2. Adrenal Weights and Quantities of Adrenal Microsomal Protein.

3. Rates of Adrenal Microsomal 17 $\alpha$-Hydroxylase Relative to Milligram Protein in Control and ACTH-Stimulated Rabbits.

4. The Rates of Adrenal Microsomal 17 $\alpha$-Hydroxylase Relative to Cytochrome P-450 concentration in Control and ACTH-Stimulated Rabbits.

5. Increase in $17 \alpha$-Hydroxylation Due to ACTH.

6. Cytochrome P-450 Content of Adrenal Microsomes Isolated from Control and ACTH-Stimulated Rabbits.

7. Total Adrenal Microsomal Cytochrome P-450 Content.

8. SDS-PAGE Peak Areas from Two, Four and Six Day ACTH-Stimulated and Control Rabbit Adrenal Microsomes. 


\section{LIST OF ILLUSTRATIONS}

Figure

PAGE

1. 17 $\alpha$-Hydroxypregnenolone shown with the numbering system used in steroid nomenclature.

2. Outline for the biosynthesis of steroid hormones.

3. Cytochrome P-450 oxygenase cycle and coupled steroid hydroxylation in microsomes.

4. 17 $\alpha$-Hydroxypregnenolone formation per milligram of microsomal protein with respect to time of assay incubation. Effect of the duration of ACTH stimulation.

5. 17 $\alpha$-Hydroxypregnenolone formation with respect to time of assay incubation. Effect of the amount of microsomal protein.

6. 17 $\alpha$-Hydroxypregnenolone formation per nanomole (nmol) cytochrome P-450 with respect to time of assay incubation. Effect of the duration of ACTH stimulation.

7. Radiochromatogram tracing of a typical initial paper chromatographic separation of $17 \alpha$-hydroxypregnenolone from substrate and other products.

8. Radiochromatogram tracing of a typical silica gel thin layer chromatographic purification of $17 \alpha$-hydroxy- $\left\{{ }^{3} \mathrm{H}\right\}$-pregnenolone isolated from initial paper chromatographic separation.

9. Representative cytochrome P-450 difference spectra.

10. Electrophoretogram scans of typical SDS-PAGE separations of adrenal microsomal proteins.

11. Electrophoretogram scans of typical protein patterns of the major bands from various multi-day stimulations as compared with controls.

12. Photograph of an SDS-PAGE gel stained for protein content.

13. Photographs of SDS-PAGE gels stained with (A) TMBZ and (B) coomassie brilliant blue. 


\section{ACKNOWLEDGEMENTS}

I would like to thank Dr. H. Richard Fevold for his training, patience and guidance throughout this project. I would also like to thank the University of Montana and the entire staff of the Chemistry Department for the graduate assistantships and the monetary support for this project and for the chemical training and experience. Thanks also goes to my wife Deborah for her expert work on the figures as well as her moral support. 
INTRODUCTION

Higher vertebrates possess two ovid or bean shaped adrenal glands embedded in fat anterior to the kidneys. The name adrenal comes from Latin ad-(near) and renal-(kidney). The cross-section of each gland reveals two clearly separated regions, an inner red colored core, the medulla, and an outer yellowish colored cortex. The two regions are distinct glands of different embryological origin. The medulla, intrinsically part of the nervous system, differentiates from the neural crests of the ectoderm, along with the sympathetic ganglia. The medullary cells are modified ganglion cells and are in close contact with the pre-ganglionic fibers of the sympathetic ennervation of the adrenal. The medulla (chromaffin tissue) produces the catecholamine hormones epinephrine (adrenalin) and norepinephrine (noradrenalin) (1).

The adrenal cortex differentiates from the mesoderm. Three zones are visible: the outer, zona glomerulosa; the center major proportion, zona fasciculata; and the inner region, that closest to the medulla, zona reticularis. The adrenal cortex produces steroid hormones. The zona fasciculata is the most responsive to adrenocorticotropic hormone (ACTH) and these cells are primarily responsible for the secretion of cortisol and corticosterone. The adrenal gland has a very high blood flow rate. A complex vascular dam and a funneling system in the cortex assures a very efficient blood supply to each cortical cell $(1,2)$. Nearly fifty steroids have been isolated from mammalian adrenocortical tissue. These steroids include compounds possessing biological activity and many biologically inactive steroids thought to be precursors, intermediates or metabolites of the active hormones. 
The biologically active compounds may be grouped into four categories based on chemical structure and biological activity. In the first group, the 11-oxygenated $\mathrm{C}_{21}$ steroids, corticosteroids, have a potent effect on carbohydrate and protein metabolism. Examples are cortisol, corticosterone and cortisone. The second group are those steroids that lack an oxygen at the 11-position (see Figure 1). The major effect of these hormones is on electrolyte and water metabolism. Examples are 11-deoxycorticosterone (DOC) and 11-deoxycortisol $\left(S_{R}\right)$. An aldehyde instead of a methyl at carbon 18 on the steroid nucleus depicts the mineral corticoids or third category of adrenocortical steroids. Aldosterone, a mineral corticoid, is potent in affecting electrolyte metabolism. The fourth group includes $C_{19}$ androgens, $C_{18}$ estrogens and $C_{21}$ progestins which are predominately synthesized in the gonadal tissue but also arise from adrenal tissue (2). An outline for the biosynthesis of steroid hormones can be seen in Figure 2.

There are a variety of hydroxylation steps in steroid hormone biosynthesis. The hydroxylations at positions 17-, 21-, 11- and 18 al1 have a common mechanism requiring oxygen, $\mathrm{NADPH}$, cytochrome P-450 and cytochrome P-450 reductase. Generation of NADPH within the adrenal cytochrome is from the activity of triphosphopyridine nucleotide linked dehydrogenases. These enzymes include malate dehydrogenase (44), isocitrate dehydrogenase and dehydrogenases of the pentose phosphate pathway (45). 


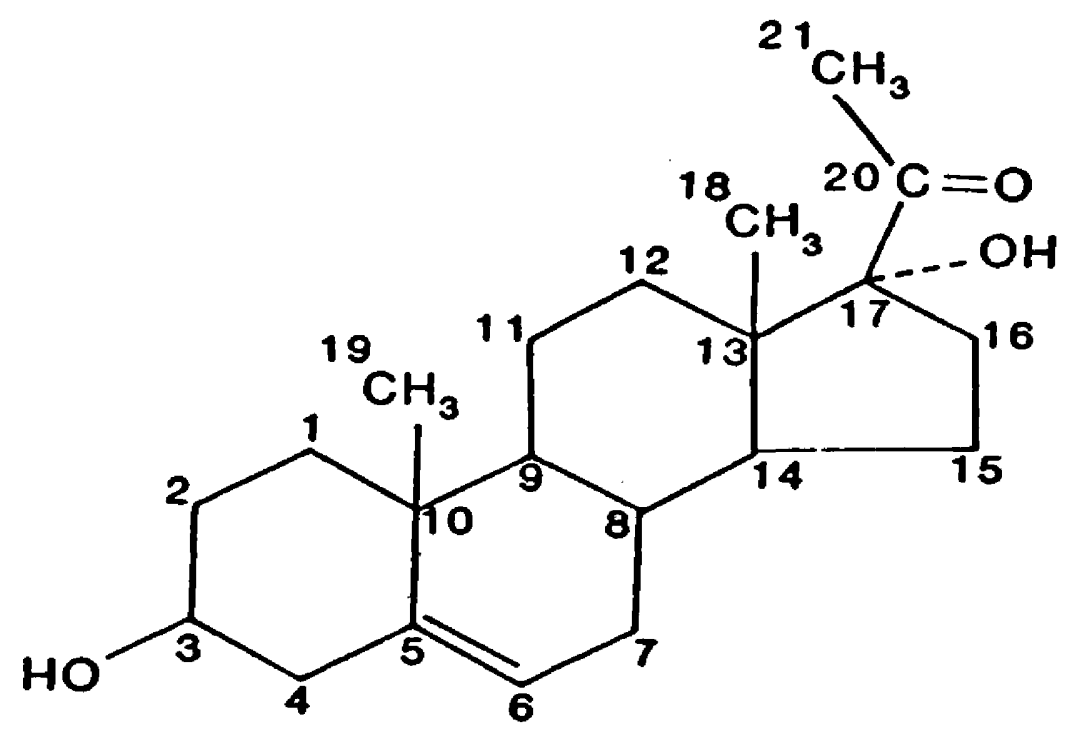

Figure 1. 17a-Hydroxypregnenolone shown with the Numbering System in Steroid Nomenclature.

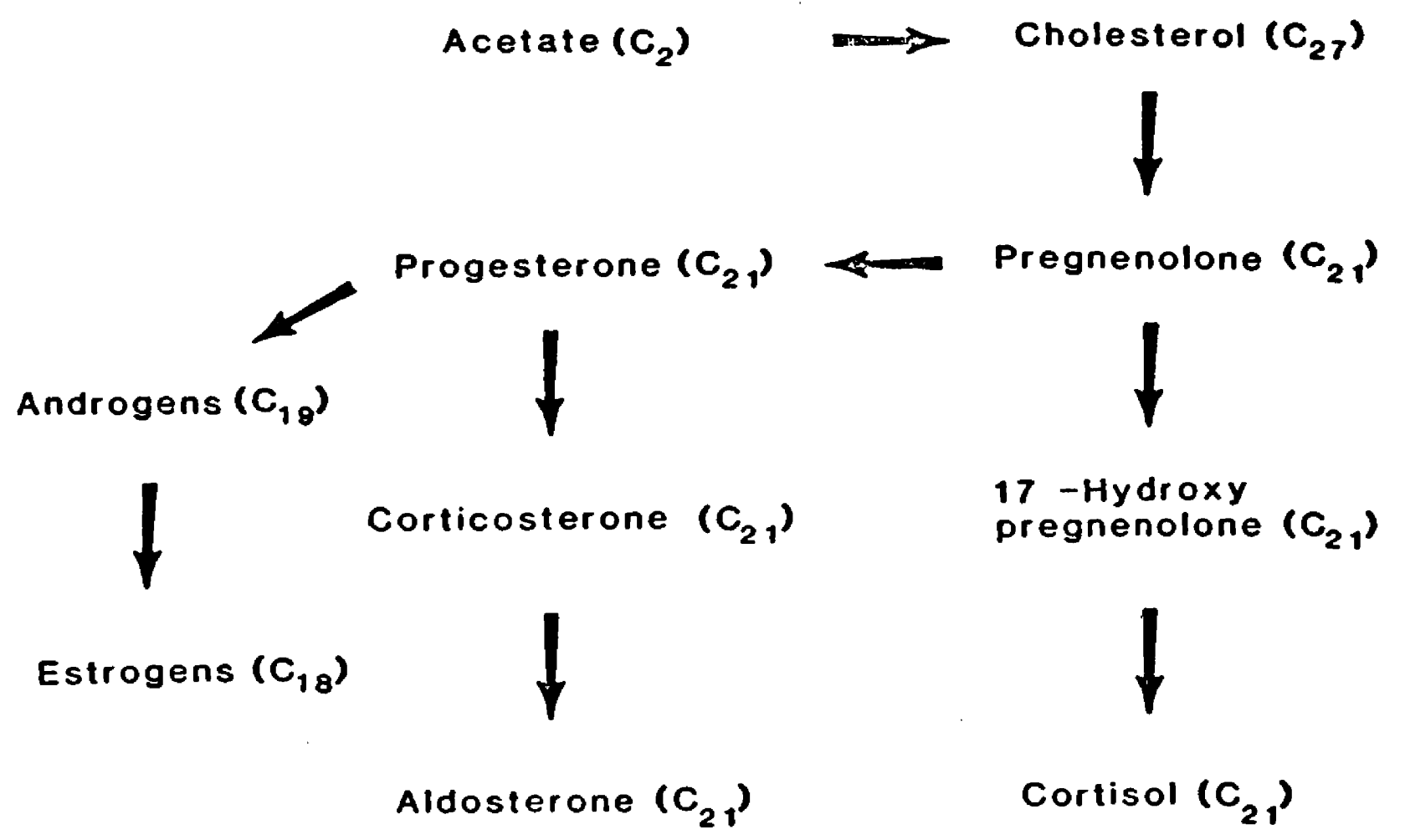

Figure 2. Outline for the Biosynthesis of Steroid Hormones. 
The steroid hydroxylating system is a mixed function oxidase (monooxygenase). In this process, two substrates--NADPH and the steroid-are oxidized (1). In the adrenal microsomal hydroxylase system, the reducing equivalents from NADPH are transferred to cytochrome P-450 through a flavoprotein, adrenodoxin, which binds directly to the cytochrome P-450. Although the precise details of the actual hydroxylation mechanism are not fully known, a summary of the scheme for microsomal hydroxylations is shown in Figure 3.

Ryan and Engel (47) discovered that steroid 21-hydroxylation of 17a-hydroxyprogesterone by bovine adrenocortical microsomes was inhibited by carbon monoxide. Garfinkle (5) and Klingenberg (6) carried this further by finding that liver microsomes contain a carbon monoxide binding pigment different from the other components of the cytochrome system having a maximal absorbence at $450 \mathrm{~nm}$. Omura and Sato (7) isolated the cytochrome and called it P-450 because of its strong absorbence at $450 \mathrm{~nm}$ in the co-complex form.

Cytochrome P-450 catalyzes hydroxylation reactions in both steroidogenic tissue and in steroid metabolizing tissues such as kidney and liver. In the liver, it serves to hydroxylate a large number of molecules prior to their elimination from the body (1). The substrates include physiologically occurring lipids such as fatty acids, prostaglandins and steroids, as well as many foreign compounds including drugs, petroleum products, anesthetics, insecticides and carcinogens (8). Multiple forms of cytochrome P-450 detected by electrophoresis are induced in hepatic microsomes to hydroxylate several types of compounds. 


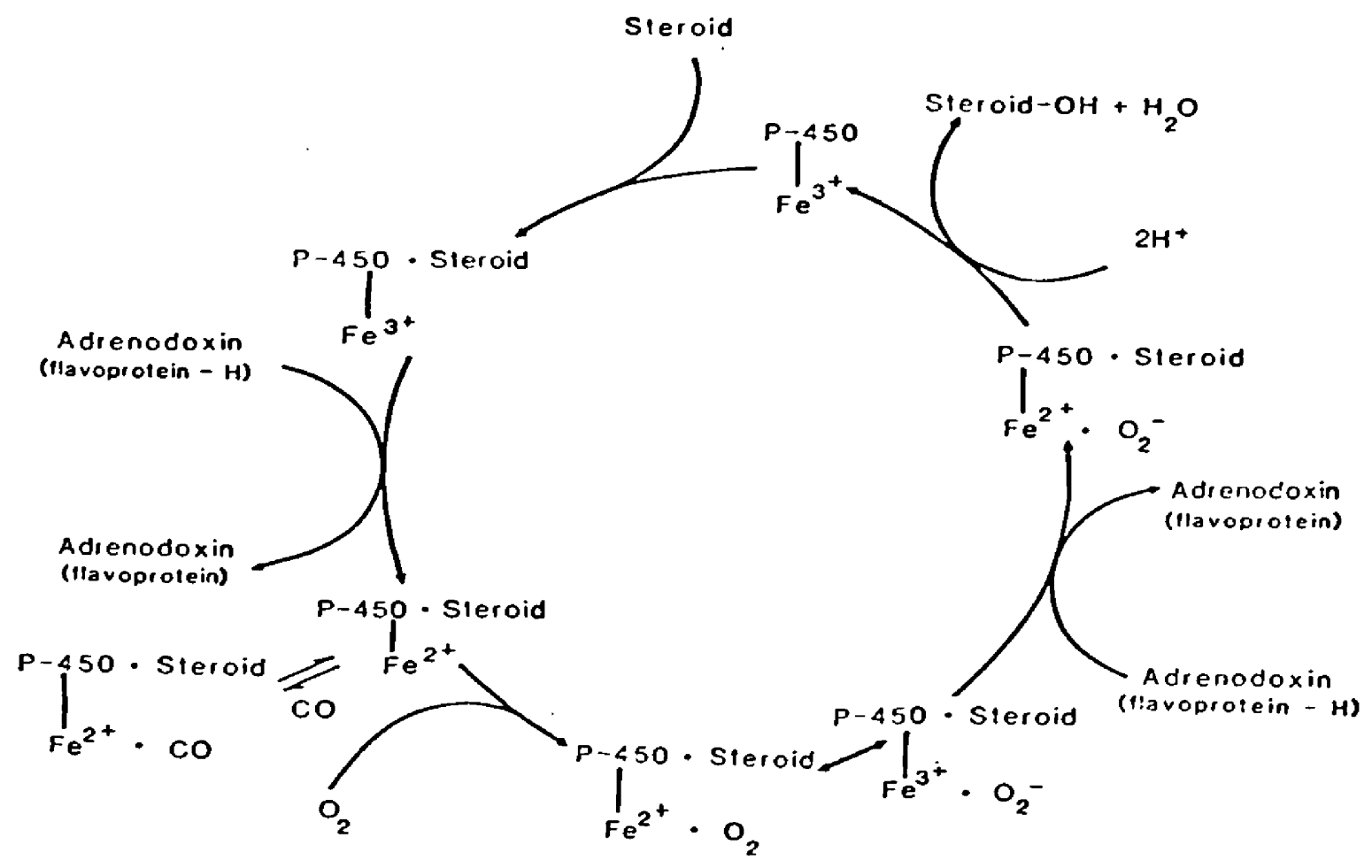

Figure 3. Cytochrome P-450 oxygenase cycle and coupled steroid hydroxylation in adrenal microsomes. Modified from reference 1 . 
Isolations and characterizations of the multiple forms of hepatic microsomal cytochrome P-450 have been reported $(33,34,49,50)$ after induction by such compounds as phenobarbital and 3-methylcholanthrene.

The adrenal mitochondria is the location of specific cytochrome P-450 molecules that catalyze the biosynthetic hydroxylations of cholesterol at positions 20 and 22 in addition to hydroxylations at positions 21 and 18 of $C_{21}$-steroids. One of the most studied cytochrome P-450s of the adrenal mitochondria is the one responsible for the side chain cleavage $\left(P-450_{S C C}\right)$ of cholesterol to yield pregnenolone. The cholesterol side chain cleavage mechanism is known to be the rate limiting step for overall steroidogenesis (10) and is under the hormonal regulation of ACTH. Studies on the hydrophobicity of cholesterol and membrane interactions while binding to $\mathrm{P}-450_{\text {SCC }}(9,10,11)$ may in the future provide excellent models for study of the adrenal microsomal hydroxylation reactions.

The complete biosyntheses of corticosteroids, androgens and estrogens involve the transport of pregnenolone across the mitochondrial membrane to the enzymes of the endoplasmic reticulum. The adrenal microsomes possess cytochrome P-450 hemoproteins that catalyze 21 - and 17-hydroxylations to steroid intermediates, which are shuttled back into the mitochondria for final biosynthetic steps such as $11 \beta$ and 18hydroxylation. The reason for the various intracellular locations of the steroid biosynthetic enzymes is uncertain. It is known that regulation of the type of glucocorticosteroid produced occurs in the microsomal fraction. Logic suggests the microsomal enzymes are in closer interaction with cytosolic factors that may fluctuate in a regulatory 
manner on a very minute scale. Purification and characterization of the cytochrome P-450 containing enzymes of the adrenal microsomes have demonstrated proteins with molecular weights ranging from 49,000 daltons (D) (46) to $60,000 \mathrm{D}(36)$. Heterogeneity of microsomal cytochrome P-450 has been demonstrated in steroid biosynthetic tissue of rat testis (51) similar to the inducible forms widely reported in liver. Differing sensitivity of two enzyme activities, namely $17 \alpha$-hydroxylase and 17,20 - lyase, to $\mathrm{CO}$ and steroid inhibition suggested the presence of two cytochromes. Evidence from immunological and electrophoretic studies, however, suggest one protein with two catalytic sites (52) in neonatal pig testis microsomes for $17 \alpha$-hydroxylase and $17,20-1 y a s e$ activity. If this is the true nature of the testis microsomal cytochrome P-450, then it is similar to the mitochondrial side chain cleavage cytochrome P-450 which has been demonstrated to catalyze three different reactions (53). Adrenocorticotropin (ACTH) is a 39 amino acid polypeptide hormone that is secreted from the anterior pituitary. It stimulates the production of corticosteroids in the adrenal (13). Much work has been done on the various modes of action of ACTH. An excellent review was written by Perón and McCarthy (14). Of particular interest were the findings of Hechter and associates (10) that the conversion of cholesterol to pregnenolone is the rate 1 imiting step stimulated by ACTH. Concurrently, researchers were investigating subsequent enzymatic synthesis of $17 \alpha-$ hydroxycorticosteroids (15) and in vitro effects of ACTH on secretions (16).

Haynes and Berthet (17) proposed adenosine-3',5'-cyclic monophosphate ( CAMP) as the mediator of ACTH action as a result of their in vitro studies. It is now well established that cAMP is the mediator or 
the second messenger that relays the ACTH signal to intracellular mechanisms. In eukaryotic systems, cAMP stimulates structural modifications of pre-existing proteins within the target tissue through phosphorylation of specific serine and threonine residues. Protein kinase, the enzyme responsible for phosphorylation, can activate or inactivate an enzyme or alter the conformation of membrane proteins in such a way that the celluIar functions associated with them are enhanced or inhibited (13). When Gill (18) analyzed a protein kinase from adrenal by SDS-PAGE the cAMP binding activity and protein kinase activity migrated as a single band. When the enzyme was preincubated with cAMP, the binding and catalytic activities separated. This work helped to confirm the findings of Brostrom et al (19), that protein kinase enzymes contained both regulatory and catalytic subunits. When the enzyme is in its undissociated state, it is inactive. When cAMP binds to the regulatory subunit, the enzyme dissociates, the catalytic site is exposed and the kinase is activated.

In addition to activating pre-existing proteins (enzymes) polypeptide hormones also increase the rate of synthesis of specific proteins. At the transcriptional level, the protein modifications that are most likely to regulate gene activity are those of histones, non-histone chromatin proteins, and RNA polymerases (13). Modification of these proteins may be seen with longer term ACTH stimulation. While phosphorylation is seen with short-term stimulation (21), transcriptional regulation may require modification by phosphorylation.

Low steroidogenic dosages of ACTH have been demonstrated to raise the levels of CAMP bound to a regulatory subunit of protein kinase (20) in adrenocortical cells. Koroscil and Gallant (2l) demonstrated ACTH 
and/or CAMP induced phosphorylation changes of several adrenocortical proteins located in various subcellular fractions. Adrenal quarters from hypophysectomized rats were subjected to in vitro incubation mixtures containing ACTH and CAMP with or without ${ }^{32} \mathrm{P}$ in the appropriate supporting buffers and additives. The subcellular fraction in question was isolated and electrophoresed. The resulting gel was dried and examined by autoradiography and showed interesting patterns of phosphorylation. In the adrenal microsome samples, ACTH and CAMP stimulated phosphorylation of $14,000,24,000$ and 54,000 dalton (D) bands. Also evident from the autoradiograms, although not mentioned, was a heavily labeled, broadened band at $61,000 \mathrm{D}$ after ACTH stimulation.

The Koroscil and Gallant studies $(21,22)$ concern short-term effects of ACTH, which are independent of mRNA transcription. The possibility of a post-transcriptional regulation through a stable mRNA still exists. Steroidogenesis is inhibited by protein synthesis inhibitors but phosphorylation is not blocked in this manner. Although speculative at this time, these phosphorylated proteins may be important in regulating the enzymes and/or other obligatory proteins in steroidogenesis. The actual proteins involved, their characterization and relationships to steroidogenesis remain on the frontier.

Though ACTH stimulates overall steroidogenesis by converting more cholesterol to pregnenolone, there is a microsomal point of regulation of the type of glucocorticosteroid produced. ACTH is secreted as a response to stress. Stimulation of steroidogenic tissue produces more glucocorticosteroids from the adrenal which in turn stimulate gluconeogenesis and supply more oxidizable fuel for the organism. In some species 
such as rabbits, birds and rodents, corticosterone is the glucocorticosteroid formed during the basal state. In rabbits chronic ACTH treatment can preferentially stimulate cortisol biosynthesis. Cortisol is a more potent glucocorticosteroid than cortisone. Fevold $(23,24,25)$ elucidated and confirmed postulates of Kass et al (26), Weliky and Engel (27) and Krum and Glenn (48) of a cortisol biosynthetic pathway that bypasses progesterone. In the cortisol pathway, ACTH stimulates the activity of $17 \alpha$-hydroxylase, the committed step of cortisol biosynthesis. The $17 \alpha$-hydroxylase activity has been found to be dependent on cytochrome P-450 in testis (29) and in adrenals (25). Specific increases in the concentration of the $17 \alpha$-hydroxylase protein have not been reported in the 1 iterature, though the activity does increase with ACTH.

The effect of ACTH on normal rat adrenal microsomal $P-450$ is an increase from about $0.6 \mathrm{nmol} P-450 / 2$ adrenals to $0.75 \mathrm{nmol} P-450 / 2$ adrenals after 4 and 6 day stimulation, $0.9 \mathrm{nmol} P-450 / 2$ adrenals after 8 days stimulation and 1.3 nmol $\mathrm{P}-450 / 2$ adrenals after 10 days stimulation (10 IU/day) (30).

Hypophysectomy lowers the level of cytochrome P-450 in rat testes microsomes. A similar effect has been noticed on the level of cytochrome P-450 in adrenal microsomes. Addition or administration of human chorionic gonadotrophin ( $h \mathrm{CG}$ ) or ACTH, respectively, restores cytochrome P-450 of testes and adrenal $(30,31)$. The decrease of cytochrome P-450 in testicular microsomes caused by hypophysectomy was accompanied by a decrease in $17 \alpha$-hydroxylase activity (31) in a parallel manner.

Purvis et al (31) postulated that some cytochrome P-450 requiring 
enzymes contain more cytochrome P-450 than others. They found that the half life $\left(T \frac{1}{2}\right)$ of the testicular microsomal P-450 of 3.3 days is very close to the $T \frac{1}{2}$ of the $C_{17-20}$ lyase and much lower than the $T \frac{1}{2}$ of 21hydroxylase, 4.5 days. Purvis suggested that the P-450 attached to the 21-hydroxylase might be more stable to degradation than a postulated free pool of cytochrome P-450 "earmarked" for insertion into the mitochondria.

Guenthner, Nebert and Menard (32) noticed changes in electrophoretic patterns of adrenal microsomal protein from intact and hypophysectomized rats. ACTH restored electrophoretic protein bands with apparent molecular weights (MW) of 53,000 D and 57,000 D. They correlated the 57,000 $\mathrm{D}$ band with aryl hydrocarbon hydroxylase (AHH) activity as determined by inhibition studies. ACTH was found to restore AHH activity to hypophysectomized rat adrenal microsomes. Different forms of hepatic cytochrome P-450 are known to have overlapping specificities $(33,34,35)$. However, the magnitudes of change in specific activities of AHH and 21hydroxylase seen upon hypophysectomy and ensuing ACTH administration suggest the adrenal microsomal activities are separate. Inhibition assays confirm this postulate, and distinct cytochrome P-450s are responsible for AHH and 21-hydroxylase activities (32). The 53,000 D band has been suggested to represent 21-hydroxylase activity (36) and the $57,000 \mathrm{D}$ band has been correlated to $\mathrm{AHH}$ activity (32).

Administration of spironolactone, a diuretic steroid, causes a depletion of microsomal cytochrome $\mathrm{P}-450$ in tissues that have a high level of $17 \alpha$-hydroxylase activity (36). The loss of P-450 by spironolactone paralleled a loss in the activity of progesterone 21 - and $17 \alpha$-hydroxylase. 
The decrease in concentration of apoproteins of adrenal P-450 in microsomes from spironolactone treated animals may be used to determine which electrophoretic bands of microsomal proteins contain cytochrome P-450. These studies suggest 21 and $17 \alpha$-hydroxylase activities possess the same $\mathrm{P}-450$ as a catalytic center. This postulate is consistent with kinetic studies (56).

Sodium dodecyl sulfate polyacryTamide gel electrophoresis (SDS-PAGE) of adrenal microsomes from guinea pig (which have high basal $17 \alpha$-hydroxylase activity) treated with spironolactone showed a decrease in concentration of the 53,000 D protein, while the 57,000 D protein appeared virtually unaffected as compared to control (36). This information suggests that both $21-$ and $17 \alpha$-hydroxylase have the same molecular weight and that both activities may have the same or very similar cytochrome P-450. 


\section{STATEMENT OF PROBLEM}

Some animals secrete cortisol and some corticosterone as their primary glucocorticosteroid. This class of compounds stimulates gluconeogenesis and has anti-inflamatory activity (1).

Rabbits normally secrete corticosterone but can be stimulated to secrete cortisol in preference to corticosterone after ACTH stimulation. ACTH stimulates the expression of adrenal $17 \alpha$-hydroxylation activity which is the committed step of cortisol biosynthesis (25).

The $17 \alpha$-hydroxylase is a cytochrome P-450 containing enzyme as determined by the fact that it displays a reduced difference spectra at $450 \mathrm{~nm}$ and is inhibited by carbon monoxide $(25,29)$. Earlier studies have shown that two to three day administration of ACTH stimulated the $17 \alpha$-hydroxylase of rabbit adrenal microsomes (25) without increases of the P-450 content.

Since ACTH stimulates overall protein synthesis in the adrenal, the lack of increase of $\mathrm{P}-450 / \mathrm{mg}$ protein (specific activity) in earlier studies (25) may have been due to increases in P-450 and in the amounts of non-P450 containing proteins concurrently, which would result in slight changes in the specific activity. An increase in $17 \alpha$-hydroxylase activity may be due to either an increase in cytochrome P-450 or an increase in a separate specificity protein which utilizes P-450 from 21-hydroxylase. This protein could bind to the steroid forming a complex which would in turn bind to P-450. A hypothesis is that a specific cytochrome P-450 for $17 \alpha$-hydroxylase is formed anew since 21-hydroxylase and other mixed function oxidases are still active during ACTH stimulation.

The aim of this research was to determine if a new $\mathrm{P}-450$ protein for $17 \alpha$-hydroxylase appears in rabbit adrenal microsomes upon stimulation 
with ACTH. Microsomes from adrenals of two, four and six day ACTHstimulated and control rabbits were assayed for $17 \alpha$-hydroxylase activity to confirm stimulation, analyzed for cytochrome P-450 content and scanned for protein bands separated by SDS-PAGE. The identities of new or intensified bands were substantiated by comparing microsomal patterns from control and stimulated rabbits with those from guinea pig, which have a high basal activity of 17a-hydroxylase. A linear increase of P-450 or a protein band seen with duration of stimulation would indicate that ACTH may be increasing 17a-hydroxylation by increasing the amount of P-450 or another specific protein.

There were four possible experimental findings. (+) and (-) denote an increase or decrease, respectively, of absorbence at $450 \mathrm{~nm}$ or of the amount of protein in a given electrophoretic band.

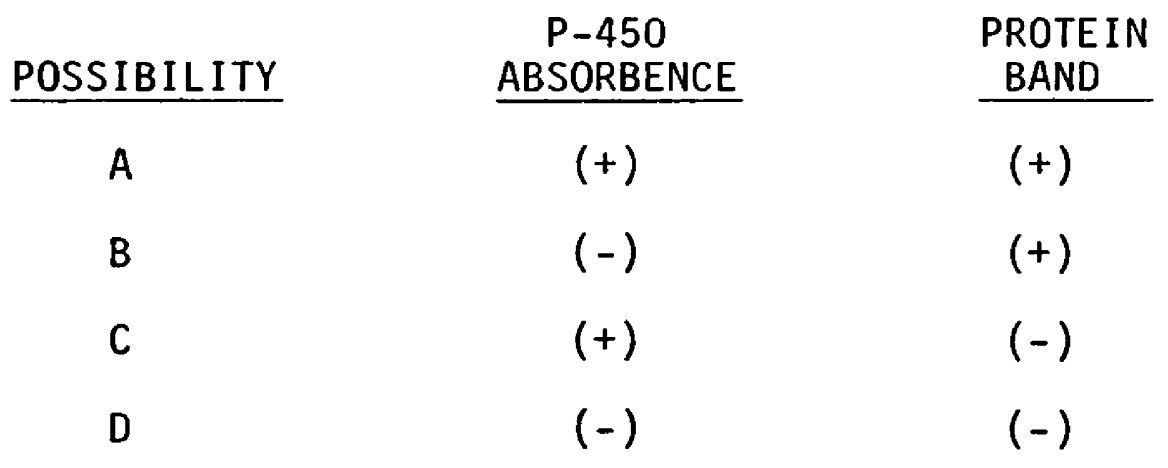

If possibility $A$ was found, this would indicate that an increase in P-450 was responsible for an increase in $17 \alpha$-hydroxylase activity. If possibility $B$ was found, then a specificity protein may have played a major role. Possibility $C$ seems unlikely since one would expect the protein band corresponding to cytochrome P-450 to increase in content if the P-450 content increases. Possibility D would suggest phosphorylation or some other covalent regulation of enzyme activity. 


\section{MATERIALS}

Rabbits - Leikam Rabbitry, Missoula, Montana

Guinea Pigs - Rocky Mountain Lab, Hamilton, Montana

ACTH - Porcine, Lot K 7000 52C, R. Schlueter 3/11/80, Armour Pharmaceutical

Chemicals (general) - Sigma

Solvents (general) - spectrograde or glass redistilled reagent grade

Steroid Standards - Sigma

Bovine serum albumin - analyzed to $99.9 \%$ protein, Sigma

$\left\{{ }^{3} \mathrm{H}\right\}$-pregnenolone - New England Nuclear specific activities - $19.3 \mathrm{uCi} / \mathrm{nmol}$ and $24.2 \mathrm{uCi} /$ nmol

Scintillation cocktail - Aquasol

Tissue homogenizer - glass

Sorvall RC-2 centrifuge, ss -34 rotor

Beckman model L2-65B ultracentrifuge, Ti-65 rotor with torque cap tubes

Cary Scanning spectrophotometer

Beckman DU-8 scanning spectrophotometer

Gilford spectrophotometer

Nuclear Chicago Liquid Scintillation counter

Packard Radiochromatogram Scanner

Whatman chromatography paper, \#1 and \#3

Quanta LQDF pre-coated thin layer chromatography plates

Acrylamide - $100 \%$, Bio-Rad

Electrophoresis apparatus - built by Jon Peterson, 11-29-80

Cyanoketone inhibitor - Sterling-Winthrop Research Institute Lang-Levy micropipettes 


\section{EXPERIMENTAL METHODS}

Adult male New Zealand white rabbits were acclimated to the animal quarters and weighed prior to injection. Twelve rabbits were injected intramuscularly twice daily for 2, 4 and 6 days at 8:00 AM and 8:00 PM \pm $1 \mathrm{hr}$. Six rabbits were injected with $25 \mathrm{IU}$ ACTH in $0.2 \mathrm{ml}$ of an injection vehicle, $5 \%$ beeswax in peanut oil, containing $0.5 \%$ phenol preservative. The other six rabbits were injected with an equal amount of 0.2 ml injection vehicle as control. At the end of the stimulation period the rabbits were weighed, anesthetized with carbon monoxide and sacrificed by exsanguination. Experiment number 1 was performed on $7 / 20 / 81$, experiment 2 on 10/6/81, experiment 3 on $6 / 17 / 81$ and experiment 4 on 5/5/81.

The adrenal glands were removed, trimmed of connective tissue on a $0.9 \%$ saline soaked gauze in a petri dish chilled on ice. The clean, chilled glands were weighed on a Roller-Smith balance and pooled in test tubes on ice as ACTH-stimulated or control. The tissue was minced into very small pieces with surgical scissors in $\mathrm{pH} 6.8,0.1 \mathrm{M}$ sodium phosphate buffer, containing $0.25 \mathrm{M}$ sucrose and $0.001 \mathrm{M}$ dithiothreitol (37). The $10 \%(w / v)$ mixture was then homogenized by ten to twenty passes with a ground glass tissue homogenizer. The homogenate was centrifuged at $9,000 \times \mathrm{g}$ for 20 minutes to remove cell wall, debris, and mitochondria. The supernatant fluid was removed and centrifuged for 10 minutes at $12,000 \times \mathrm{g}$ to remove heavier mitochondria. The resulting supernatant fluid was centrifuged at $17,500 \times \mathrm{g}$ for 30 minutes to remove the mitochondria fragments and heavy microsome fraction.

The microsomal fraction $\left(M_{S}\right)$ used in these studies was sedimented 
at $105,000 \times g$ for $60 \mathrm{~min}$ from the $17,500 \times \mathrm{g}$ supernatant fluid. The pellet was resuspended in a small volume of $\mathrm{pH} 6.8,0.1 \mathrm{M}$ sodium phosphate buffer containing $0.154 \mathrm{M} \mathrm{KCl}$ and $0.001 \mathrm{M}$ dithiothreitol and centrifuged for $60 \mathrm{~min}$ at $105,000 \times \mathrm{g}$. This $\mathrm{KCl}$ wash step was repeated a second time. The final $M_{S}$ pellet was resuspended in $1.5 \mathrm{ml}, 0.1 \mathrm{M}$ sodium phosphate buffer $\mathrm{pH} 7.0$, containing $0.25 \mathrm{M}$ sucrose.

A volume of $0.75 \mathrm{ml}$ was removed from the final suspension for electrophoretic samples. After removal of $0.06 \mathrm{ml}$ for Lowry (38) protein determination, the remaining $0.69 \mathrm{ml}$ was mixed with glycerol to make a $20 \%$ glycerol solution to protect the protein from serious damage caused by freezing. The $M_{S}: g$ lycerol, 80:20 mixture was divided into seven vials holding $0.120 \mathrm{ml}$ each. One vial was set aside on ice for a few hours for electrophoresis with fresh sample, the remaining vials were stored at $-20^{\circ} \mathrm{C}$ for up to three months with no apparent alteration of electrophoretic mobility or pattern.

The remaining $0.75 \mathrm{ml}$ resuspended $M_{S}$ pellet was diluted with $0.1 \mathrm{M}$ sodium phosphate buffer, $\mathrm{pH} 7.0$, containing $0.25 \mathrm{M}$ sucrose (no DTT) to a volume which allowed $0.5 \mathrm{ml}$ per incubation flask, $1.0 \mathrm{ml}$ for cytochrome P-450 determination (7) and $1.0 \mathrm{ml}$ for Lowry protein determination (38). All dilutions were done at $4^{\circ} \mathrm{C}$ and the samples kept on ice.

Protein determinations were done by the Lowry modification (38) of the Folin-Ciocalteu reaction using crystaline bovine serum albumin as a standard.

All of the $17 \alpha$-hydroxylase enzyme activity assays were carried out in $25 \mathrm{ml}$ Erlenmeyer flasks containing a total volume of $2.0 \mathrm{ml}$. The flasks were incubated for 0,2 and 4 min in a shaking water bath at 
$37^{\circ} \mathrm{C}$. The incubations were performed with $\left\{{ }^{3} \mathrm{H}\right\}$-pregnenolone together with final concentrations of $0.5 \mathrm{mM} \mathrm{NADPH}, 0.1 \mathrm{mM}$ cyanoketone inhibitor, $2.0 \mathrm{mg}$ glucose-6-phosphate and $2 \mathrm{U}$ glucose-6-phosphate dehydrogenase. Substrate purity was checked by thin layer chromatography and, if necessary, purified by paper chromatography prior to utilization in the assays. The $\left\{{ }^{3} \mathrm{H}\right\}$-pregnenolone, $2.0-5.0 \mu \mathrm{Ci}$ mixed with cold pregnenolone to give final concentrations of $0.05-1.0 \mu \mathrm{M}$, was added to each incubation flask in $200 \mu l$ of an ethanol:propylene glycol $(1: 1, v / v)$ solution prior to the other incubation components. The cyanoketone inhibitor was added second in $50 \mu \mathrm{l}$ of a $40 \mathrm{mM}$ solution in a similar solvent mixture. The ethanol was evaporated under a stream of nitrogen in a water bath at $45^{\circ} \mathrm{C}$ prior to the addition of the other incubation components. Both NADPH and an NADPH generating system were included to assure this critical cofactor was not limiting at any time during the assays. The gas phase was air.

The reactions were started by adding $0.5 \mathrm{ml}$ of prewarmed $M_{S}$ suspension to $1.5 \mathrm{ml}$ of prewarmed modified Krebs-Ringer buffer containing the substrate and cofactors. Reactions were stopped by the rapid addition of $5 \mathrm{ml}$ cold $\mathrm{CH}_{2} \mathrm{Cl}_{2}$, thorough mixing and placing the flasks on ice. Reaction flasks containing the $2.0 \mathrm{ml}$ incubation media and $5.0 \mathrm{ml}$ $\mathrm{CH}_{2} \mathrm{Cl}_{2}$ were stored at $-20^{\circ} \mathrm{C}$ until analyzed for product formation.

\section{EXTRACTION AND ANALYSIS}

The frozen incubation media were thawed, diluted with $3.0 \mathrm{ml}$ glass redistilled $\mathrm{H}_{2} \mathrm{O}$ and extracted twice with double volumes ( $10 \mathrm{ml}$ ) of cold spectrograde $\mathrm{CH}_{2} \mathrm{Cl}_{2}$. The two extracts were removed with a serum lifter 
and pooled. The solvent was evaporated and the extract concentrated in the tip of a citric acid tube by $\mathrm{CH}_{2} \mathrm{Cl}_{2}$ :methanol, 1:1 rinses. Fifty micrograms each of $17 \alpha$-hydroxyprogesterone and progesterone were added to the samples during the rinse steps as internal chromatography standards. The steroid products were separated from the pregnenolone substrate by paper chromatography using the Zaffaroni method (39) for the initial separation. The paper chromatograms were developed in a heptane/formamide system for one hour after the heptane had reached the end of the paper, followed by development in benzene/formamide until the solvent front was one $\mathrm{cm}$ from the end of the strip. The paper strips were allowed to dry and the ultra violet absorbing areas corresponding to the standards were marked. The chromatograms were scanned for $\left\{{ }^{3} \mathrm{H}\right\}$ - labeled areas. That area corresponding to $17 \alpha-$ hydroxypregnenolone was eluted with $15 \mathrm{ml}$ ethanol. The solvent was evaporated and the extract concentrated as before. Twenty-five micrograms each of internal standards 11ß-hydroxyprogesterone and 11-deoxycorticosterone (DOC) were added to one half of the residue and applied to thin layer chromatogram plates on alternate lanes. Twenty-five micrograms each of $17 \alpha$-hydroxypregnenolone, 21-hydroxypregnenolone, 17-hydroxyprogesterone and 11-deoxycorticosterone were applied to the lanes adjacent to the sample lanes. The solvent system used for the development of the TLC plates was cyclohexane:ethyl acetate, 85:115. The TLC plates were developed for two successive one hour periods allowing them to dry between developments. The developed plates were scanned and the areas corresponding to $17 \alpha$-hydroxy- $\left\{{ }^{3} \mathrm{H}\right\}$-pregnenolone were scraped into vials and quantified by liquid scintillation spectrom- 
etry using Aquasol as the counting fluid. To evaluate the effectiveness of the inhibition of the 3B-ol-dehydrogenase activity by cyanoketone, the progesterone-pregnenolone and 17a-hydroxyprogesterone-DOC areas of the paper chromatograms were eluted with $15 \mathrm{ml}$ ethanol. After evaporation of the solvent, each residue was acetylated with a $4: 1$ mixture of pyridine:acetic anhydride for twelve hours. One-half $\mathrm{ml}$ of ethanol was added to stop the reaction and the resulting mixture was evaporated. The products were chromatographed on paper in a heptane/formamide system and on thin layer plates in a $\mathrm{CH}_{2} \mathrm{Cl}_{2}$ :methanol: $\mathrm{H}_{2} \mathrm{O}, 150: 2.5: 0.25$, system. The areas corresponding to pregnenolone $3 \beta$-acetate and deoxycorticosterone 21-acetate were quantified by the methods given above.

Micromolar conversion rates were calculated from the percent of the substrate converted and from the specific activity of the added substrate. All rates were determined from slopes drawn from linear least squares analysis. Percent recovery of $17 \alpha$-hydroxy $\left\{{ }^{3} \mathrm{H}\right\}$-pregnenolone from the aqueous incubation media was calculated by adding a known quantity of labeled product to an incubation media containing thawed guinea pig microsomes, extracting, chromatographing and counting as for the assay incubations.

Cytochrome P-450 content was determined by the method of Omura and Sato (7). Sodium thiosulfate was used as the reducing agent and carbon monoxide was bubbled through the solution at a rate of two bubbles/sec. The molar extinction coefficient of $91.1 \mathrm{~cm}^{-1} \mathrm{mM}^{-1}$ was used for all cytochrome P-450 calculations. 
SDS-PAGE Of MICROSOMAL SAMPLES

Sodium dodecyl sulfate polyacrylamide gel electrophoresis (SDSPAGE) was performed by the method of Laemmli (40) with modifications by Studier (41) and Menard, Stripp and Gillette (36). The final concentrations of the contents of the separating gel contained $7.5 \%$ acrylamide:bis, $98: 2,0.015 \mathrm{M}$ Tris-HCl pH 8.8, 0.001\% (w/v) SDS, 2 mM EDTA pH 7.2, $0.0005 \%(v / v)$ TEMED, $50 \%(v / v) \mathrm{H}_{2} \mathrm{O}$ and $0.1 \%$ ammonium persulfate. The total volume of $30 \mathrm{ml}$ separating gel was pipetted into a glass plate sandwich with a $1.5 \mathrm{~mm}$ space between the plates. The spacer gel contained $2.8 \%(w / v)$ acrylamide:bis, $98: 2,0.06 \mathrm{M}$ Tris-HCl pH 6.8, 0.01\% (w/v) SDS, $2 \mathrm{mM}$ EDTA pH 7.2, $0.5 \mathrm{~m} \%$ (v/v) TEMED, $67 \% \mathrm{H}_{2} \mathrm{O}, 0.1 \%(\mathrm{w} / \mathrm{v})$ ammonium persulfate. This solution, total volume of $10.5 \mathrm{ml}$, was pipetted over the top edge of the polymerized separating gel and an eleven well comb was inserted to displace polyacrylamide for sample application. After polymerization, the wells were rinsed with electrophoresis buffer and placed in the electrophoresis apparatus. The electrophoresis buffer contained $9 \mathrm{~g}$ Tris, $43.2 \mathrm{~g}$ glycine, $7.5 \mathrm{ml} 20 \% \mathrm{SDS}, 10 \mathrm{ml} 0.2 \mathrm{M}$ EDTA and $\mathrm{H}_{2} \mathrm{O}$ to a final volume of 1.5 liters.

Volumes of microsomal protein samples were mixed with the appropriate volume of sample buffer (given below) to achieve a $1 \mathrm{mg} / \mathrm{ml}$ solution. This sample was vortexed, boiled for one minute, then vortexed again for optimum interaction of the protein with SDS. Forty $\mu 1$ of each $1 \mu g / \mu l$ sample was applied to each sample well. Each gel contained at least duplicate samples of the control and ACTH stimulated microsomes in adjacent wells and in most cases triplicate applications were 
made. The sample buffer contained $0.063 \mathrm{M} \mathrm{Tris-HCl} \mathrm{pH} 6.8,10 \%(\mathrm{v} / \mathrm{v})$ glycerol, 1\% (v/v) B-mercaptoethanol, $1 \%(w / v)$ SDS, $0.00125 \%(w / v)$ bromophenyl blue in $\mathrm{H}_{2} \mathrm{O}$. For low protein concentrations, onethird the volume of $\mathrm{H}_{2} \mathrm{O}$ was used to increase the relative concentration of the other components and assure thorough coating of the protein with SDS.

The $\beta$-mercaptoethanol was omitted for the heme staining procedures. The standard proteins used for molecular weight markers were ovalbumin $(43,000 \mathrm{D})$, glutamate dehydrogenase $(53,000 \mathrm{D})$, catalase $(58,000 \mathrm{D})$ and bovine serum albumin $(68,000 \mathrm{D})$.

A11 samples were applied to the sample wells under the electrophoresis buffer level on the slab gel with $20 \mu l$ disposable pipettes. Care was taken to exclude air bubbles. The samples were electrophoresed at $15 \mathrm{~mA}$ until the tracking dye entered the separating gel, then the amperage was increased to and kept at $25 \mathrm{~mA}$ until the electrophoresis was complete ( 5 to 6 hours, tracking dye $1 \mathrm{~cm}$ from bottom). Resolution of bands was found to be better when electrophores is was done in the cold room. The gel was stained for protein in $1 \mathrm{~g}$ coomassie brilliant blue mixed in $440 \mathrm{ml}$ of methanol:glacial acetic acid: $\mathrm{H}_{2} \mathrm{O}$, 200:40:200, for one hour then destained in methanol:glacial acetic acid: $\mathrm{H}_{2} \mathrm{O}, 100: 150: 1750$.

A method for staining heme prosthetic groups (42) was used on SDSPAGE gels immediately after the gel was electrophoresed. One hundred and fifty $\mathrm{mg} 3,3^{\circ}, 5,5^{\prime}$-tetramethylbenzidine (TMBZ) was allowed to dissolve in $100 \mathrm{ml}$ methanol on a magnetic stirrer in the dark (photosens itive reaction takes place otherwise). The gel was placed in $233 \mathrm{ml}$ 
$0.25 \mathrm{M}$ sodium acetate $\mathrm{pH} 5.0$. The $6.3 \mathrm{mM} \mathrm{TMBZ} /$ methanol solution was added to the acetate buffer containing the gel to make the final ratio TMBZ/methanol:acetate, 3:7. The gel was allowed to preincubate with this mixture one to two hours in the dark with swirling every 15 minutes to dissolve any TMBZ precipitate that forms. Hydrogen peroxide was added to a final concentration of $30 \mathrm{mM}$ to resolve the heme prosthetic groups. The heme stained bands could be seen within three minutes and reached full intensity after three hours. The gel was then placed in isopropyl alcohol:acetate buffer, $3: 7$ to remove background stain and to intensify the stained bands. Photography or scanning was done within a few hours after addition of the isopropyl alcohol:acetate buffer solution. All traces of heme stain were gone within 24 hours. The same gel could then be stained for protein using the coomassie method.

After protein staining and clarification, the gel was dried for scanning, photography and storage. Porous cellophane, designed for SDS-PAGE gel drying, was wetted and placed on both sides of the gel. All air bubbles were removed and the gel placed in the slab gel dryer (Bio-Rad). Drying took 12 hours under vacuum, three hours if the bottom plate of the dryer was placed in a hot water bath and 1.5 hours if a heated slab gel dryer was used.

Scanning was done at $560 \mathrm{~nm}$ on a Beckman DU-8 scanning spectrophotometer. Slit width was $0.5 \mathrm{~nm}$, span was $0.250 . D$., scan speeds for optimum resolution were $0.1 \mathrm{~cm} / \mathrm{min}$ for the gel and $1.0 \mathrm{~cm} / \mathrm{min}$ for the chart. Molecular weight determinations were done by entering the relative mobilities of the standard proteins into the DU-8's program for 
subsequent scanning of the sample lanes. Molecular weights of the sample protein bands were then autocorrelated to a linear regression of the programmed molecular weights.

The areas were calculated by triangulation, then corrected for recurring variables. Due to the variability inherent in the coomassie brilliant blue staining procedure, variations were observed in the staining intensity of duplicate and triplicate gels of the same samples with the same amount of applied protein. Duplicate lanes of control and ACTH stimulated samples within the same gel showed excellent reproducibility. Assuming that control microsome gel patterns are consistent from one preparation to the next, the reproducibility seen within one gel was standardized with the other gels. Control area values were set to the most reproducible control area value and a ratio obtained. These ratios (calculated for each well of each gel) were used as correction factors to correct the staining intensity of the ACTH stimulated microsome sample, relative to the adjacent control sample, to duplicate gels. The amount of protein applied to each sample well was close to and corrected to exactly $40 \mu \mathrm{g} / \mathrm{we} 11$. 


\section{RESULTS}

The ACTH stimulated rabbits exhibited a smaller weight gain than the controls during the stimulation periods, as shown in Table 1.

The ACTH-stimulated adrenals were larger than the controls. The weight difference was most striking after six days of stimulation. The amount of microsomal protein is shown in Table 2 . The microsomal protein content was found to range from $0.25 \%$ to $0.43 \%$ of the total adrenal weight with a mean value of $0.34 \% \pm 0.06 \%$.

As shown in Table 3 and Figure 4 , the rates of 17a-hydroxylation relative to milligram microsomal protein ranged from $0.078 \pm 0.020$ to $0.115 \pm 0.003 \mathrm{nmol} \mathrm{min}^{-1} \mathrm{mg}^{-1}$ for control animals. The two day ACTH stimulated rate was $0.429 \pm 0.040 \mathrm{nmol} \mathrm{min}^{-1} \mathrm{mg}^{-1}$, the four day ACTH stimulated rate was $0.631 \pm 0.120 \mathrm{nmol} \mathrm{min}^{-1} \mathrm{mg}^{-1}$, and the six day ACTH stimulated rate was $0.440 \pm 0.070 \mathrm{nmol} \mathrm{min}^{-1} \mathrm{mg}^{-1}$. The rates of $17 \alpha-$ hydroxylation were proportional to the amount of microsomal protein in the incubation flask. This information is plotted and summarized in Figure 5.

The values of the velocities expressed relative to nmol cytochrome P-450 are less variable in control samples than the velocities expressed relative to milligram micromosal protein (see Figure 6 and Table 4 \& 5). The same general patterns of stimulation are evident when rates are calculated relative to nmol $\mathrm{P}-450$ and $\mathrm{mg}$ microsomal protein.

The rates as expressed in Tables 3 and 4 show that the four day ACTH stimulated tissue have the highest $17 \alpha$-hydroxylase activity, while the two and six day. ACTH stimulation have slightly lower activities. In some of the kinetic measurements, the rates were slightly lower from 
Table 1.

Comparison of Body Weights of Control and ACTH-Stimulated Rabbits.

\begin{tabular}{|c|c|c|c|c|c|c|c|}
\hline \multirow{3}{*}{$\begin{array}{l}\text { Exp. } \\
\text { No. }\end{array}$} & \multirow{3}{*}{$\begin{array}{l}\text { Days } \\
\text { Stim }\end{array}$} & \multirow{2}{*}{\multicolumn{2}{|c|}{$\begin{array}{l}\text { AVERAGE } \\
\text { BODY WEIGH } \\
\text { ACTH }\end{array}$}} & \multirow{2}{*}{\multicolumn{2}{|c|}{$\begin{array}{l}g \\
\text { CONTROL }\end{array}$}} & \multirow{3}{*}{$\begin{array}{l}\text { ratio } \\
\mathrm{ACTH}\end{array}$} & \multirow{3}{*}{$\begin{array}{l}\text { After } \\
\begin{array}{l}\text { Before } \\
\text { CONTROL }\end{array}\end{array}$} \\
\hline & & & & & & & \\
\hline & & Before & After & Before & After & & \\
\hline 1 & 2 & $2455(6) *$ & $2482(6)$ & $2761(6)$ & $2813(6)$ & 0.998 & 1.020 \\
\hline 2 & 4 & $1999(6)$ & $2071(6)$ & $2154(6)$ & $2253(6)$ & 1.036 & 1.046 \\
\hline 3 & 4 & $2595(6)$ & $2646(6)$ & $2585(6)$ & $2657(6)$ & 1.020 & 1.030 \\
\hline 4 & 6 & $1736(7)$ & $1891(7)$ & $1727(7)$ & $1910(7)$ & 1.089 & 1.106 \\
\hline
\end{tabular}

* number of animals in parentheses 
Table 2.

Adrenal Weights and Quantities of Adrenal Microsomal Protein

\begin{tabular}{|c|c|c|c|c|c|c|c|}
\hline \multirow[b]{2}{*}{$\begin{array}{l}\text { Exp. } \\
\text { No. }\end{array}$} & \multirow[b]{2}{*}{$\begin{array}{l}\text { Days } \\
\text { Stim }\end{array}$} & \multicolumn{2}{|c|}{ AVERAGE } & \multicolumn{2}{|c|}{ TOTAL MICROSOMAL } & \multirow[b]{2}{*}{ MICROSOMAL } & \multirow[b]{2}{*}{$\begin{array}{c}\text { PROTEIN, } \mathrm{mg} / \mathrm{g}^{\#} \\
\text { CONTROL }\end{array}$} \\
\hline & & $\begin{array}{l}\text { ADRENAL } \\
\text { ACTH }\end{array}$ & $\begin{array}{r}\text { WEIGHTS, mg } \\
\text { CONTROL }\end{array}$ & $\begin{array}{l}\text { PROTEIN, } \\
\text { ACTH }\end{array}$ & $\begin{array}{l}\mathrm{mg} \\
\text { CONTROL }\end{array}$ & & \\
\hline 1 & 2 & $64.4^{\star}$ & 54.8 & 2.88 & 2.65 & 0.31 & 0.34 \\
\hline 2 & 4 & 74.3 & 59.7 & 2.54 & 1.88 & 0.24 & 0.22 \\
\hline 3 & 4 & 87.5 & 87.2 & 3.45 & 3.33 & 0.27 & 0.27 \\
\hline 4 & 6 & 68.3 & 49.3 & 3.51 & 1.68 & 0.36 & 0.24 \\
\hline
\end{tabular}

* Twelve adrenals in each pool

\# Average mg microsomal protein content per gram adrenal tissue 
Table 3.

Rates of Adrenal Microsomal 17 $\alpha$-Hydroxylation Relative to Milligram Protein in Control and ACTH Stimulated Rabbits.

\begin{tabular}{lccccccc}
\hline $\begin{array}{l}\text { Exp. } \\
\text { No. }\end{array}$ & $\begin{array}{l}\text { Days } \\
\text { Stim }\end{array}$ & $\begin{array}{l}\text { PREGNENOLONE } \\
\text { PRTH }\end{array}$ & CONTROL & ACTH & CONTROL & RATIO OF RATES \\
\hline 1 & 2 & 0.5 & 0.120 & 0.103 & $0.429 \pm 0.040$ & $0.087 \pm 0.003$ & 4.93 \\
2 & 4 & 0.5 & 0.157 & 0.100 & $0.631 \pm 0.120$ & $0.115 \pm 0.003$ & 5.49 \\
3 & 4 & 0.05 & 0.110 & 0.105 & $0.492 \pm 0.070$ & $0.082 \pm 0.004$ & 6.00 \\
4 & 6 & 0.975 & 0.095 & 0.048 & $0.440 \pm 0.070^{*}$ & $0.078 \pm 0.028$ & 5.64 \\
\hline
\end{tabular}

\# Ratio of rates is the ratio of ACTH/CONTROL rates to show fold stimulation

* Due to technical difficulties, the two minute counts were not recovered. This rate with the standard deviation was calculated from duplicate 4 min incubation flasks

Standard errors are given

Correlations of all slopes were $>0.99$ except for exp. 4 control which was 0.97 


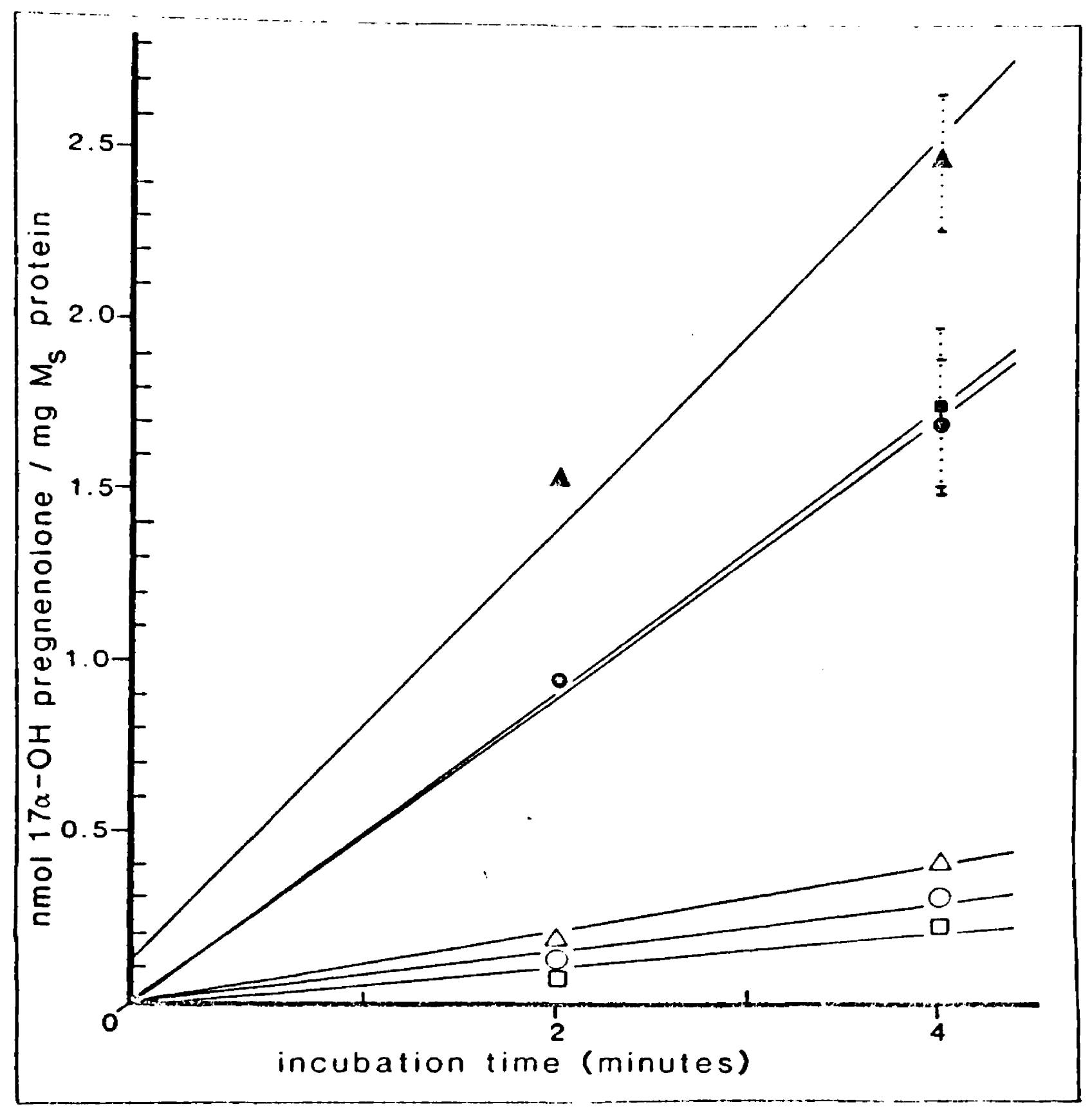

Figure 4. 17a-Hydroxypregnenolone formation per milligram of microsomal protein with respect to time of assay incubation. Effect of the duration of ACTH stimulation. Two day ( $\bullet$ ), four day $(\boldsymbol{\Delta})$ and six day (-) ACTH stimulated and control (O, $\triangle, \square$ ) samples are shown. Values for the rates (slopes) are given in Table 3. 


\section{Table 4.}

The Rates of Adrenal Microsomal 17 $\alpha$-Hydroxylase Relative to Cytochrome P-450 Concentration in Control and ACTH Stimulated Rabbits.

\begin{tabular}{|c|c|c|c|c|c|c|c|}
\hline \multirow{2}{*}{$\begin{array}{l}\text { Exp. } \\
\text { No. }\end{array}$} & \multirow{2}{*}{$\begin{array}{l}\text { Days } \\
\text { Stim }\end{array}$} & \multirow{2}{*}{$\begin{array}{c}\mu M \\
\text { PREGNENOLONE }\end{array}$} & \multicolumn{2}{|c|}{ PROTEIN, mg } & \multicolumn{2}{|c|}{$v, \mathrm{nmol} \cdot \min ^{-1} \cdot \mathrm{nmol} \quad \mathrm{P}-450^{-1}$} & \multirow[b]{2}{*}{ RATIO OF RATES ${ }^{\#}$} \\
\hline & & & ACTH & CONTROL & ACTH & CONTROL & \\
\hline 1 & 2 & 0.5 & 0.120 & 0.103 & $0.335 \pm 0.029$ & $0.070 \pm 0.004$ & 4.79 \\
\hline 2 & 4 & 0.5 & 0.157 & 0.100 & $0.508 \pm 0.095$ & $0.093 \pm 0.003$ & 5.46 \\
\hline 3 & 4 & 0.05 & 0.110 & 0.105 & $0.492 \pm 0.069$ & $0.072 \pm 0.004$ & 6.83 \\
\hline 4 & 6 & 0.975 & 0.095 & 0.048 & $0.370 \pm 0.055^{\star}$ & $0.060 \pm 0.004$ & 6.17 \\
\hline
\end{tabular}

\# Ratio of rates is the ratio of ACTH/CONTROL rates to show fold stimulation

* Oue to technical difficulties, the two minute counts were not recovered. This rate, with the standard deviation, was calculated from values obtained from duplicate 4 min incubation flasks.

Standard errors are given Correlations of all slopes were 0.99 except for exp. 4 control which was 0.97 . 


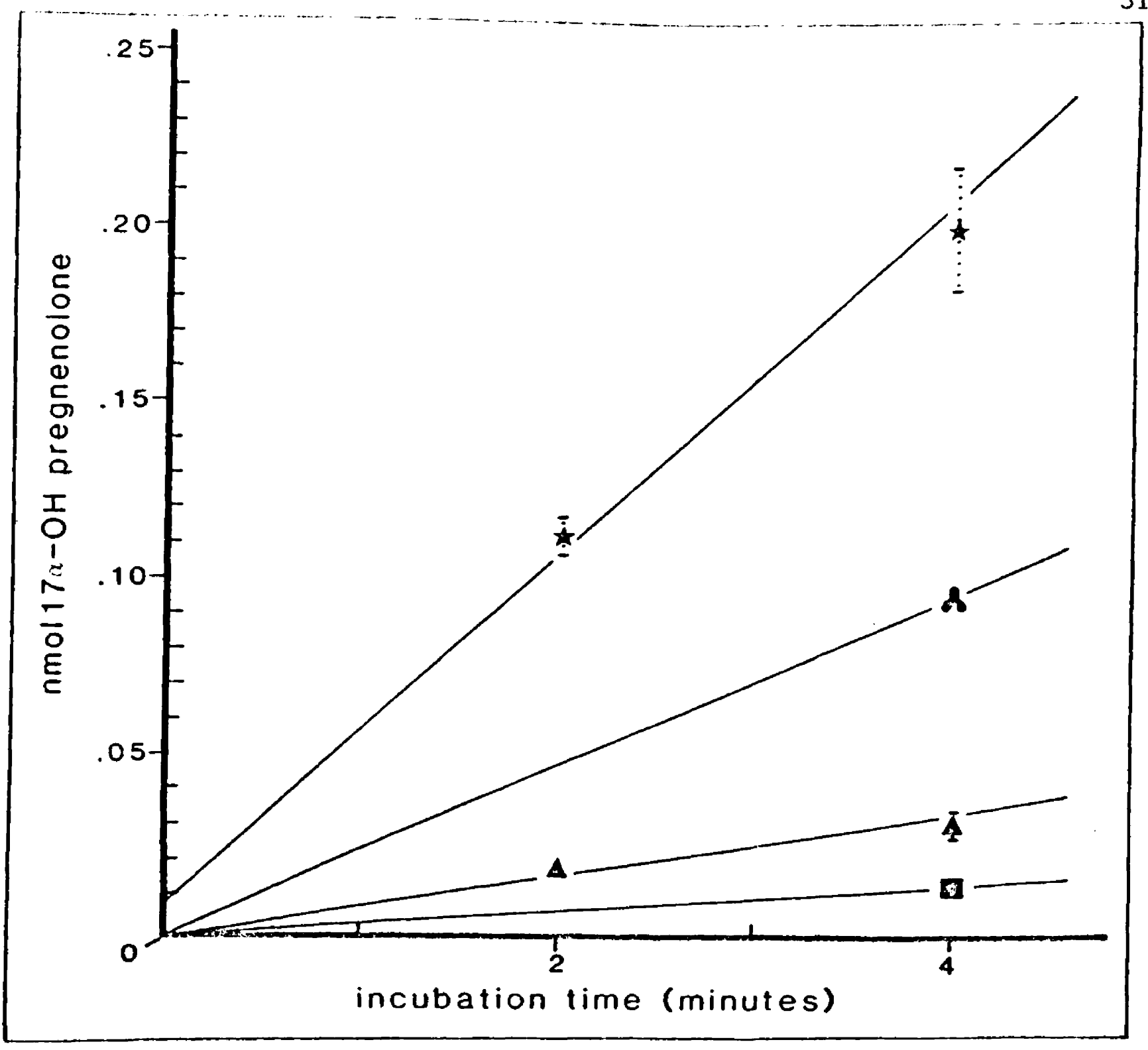

Figure 5. 17a-Hydroxypregnenolone formation with respect to time of assay incubation. Effect the amount of microsomal protein. Amount of protein used was: $(\star), 0.12 \mathrm{mg}$ and $(\boldsymbol{A}), 0.06 \mathrm{mg} \mathrm{ACTH}$ stimulated; $(\Delta), 0.103 \mathrm{mg}$ and $(\boldsymbol{D}), 0.0515 \mathrm{mg}$ control tissue. Experiment 3, 4 day. 


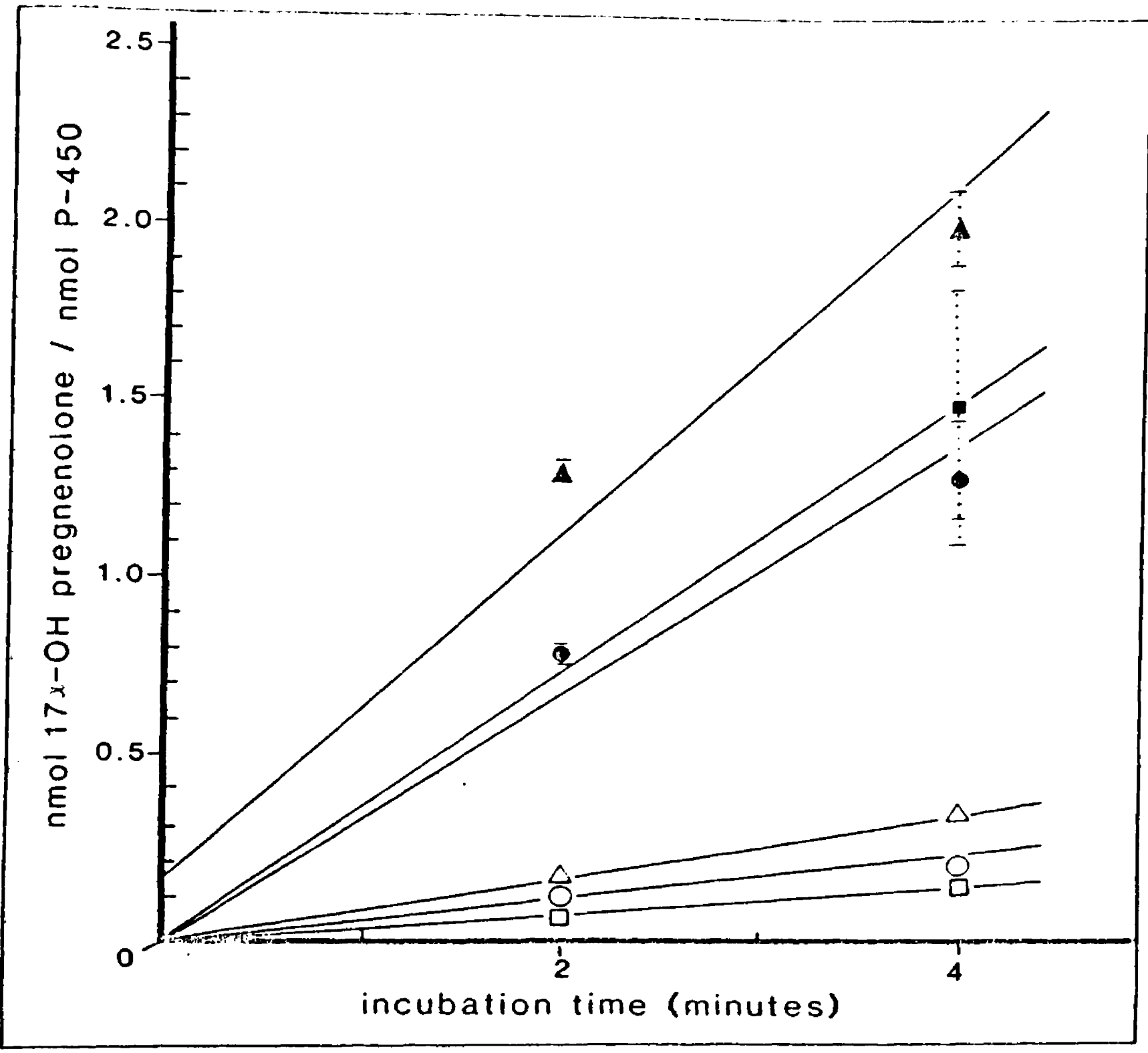

Figure 6. 17a-Hydroxypregnenolone formation per nmol cytochrome $\mathrm{P}-450$ with respect to time of assay incubation. Effect of the duration of ACTH stimulation. Two day $(\bullet)$, four day $(\boldsymbol{\Delta})$ and six day (-) ACTH and control (O, $\Delta, \square$ ) samples are shown. Values of the rates are given in Table 4. 
two to four than zero to two minutes. The difference between an average slope and the zero to two minute slopes were insignificant and average slopes were used in calculating the rates.

The steroid product mixtures were extracted from the incubation mixtures and separated by paper and thin layer chromatography as discussed in Experimental Methods. A representative paper chromatography scan can be seen in Figure 7. The stippled area in Figure 7 corresponds to $17 \alpha$-hydroxypregnenolone and was eluted for further purification by thin layer chromatography (Figure 8 ) and quantification. The stippled area in Figure 8 was scraped from the plate for final quantification by liquid scintillation spectrometry. The hatched area in Figure 7 was eluted and identified as 11-deoxycorticosterone. The rate of its formation was $0.246 \pm 0.006 \mathrm{nmol} / \mathrm{min} / \mathrm{mg}$ in control and $0.254 \pm 0.038 \mathrm{nmol} / \mathrm{min} / \mathrm{mg}$ in incubations with microsomes from ACTHstimulated adrenals. This product was of no significance to the main purpose of this thesis, but confirmed the specificity of the $17 \alpha$-hydroxylase stimulation (56).

Fresh guinea pig adrenal microsomes were found to contain 2.48 nmol cytochrome $\mathrm{P}-450 / \mathrm{mill}$ igram microsomal protein. The rate of $17 \alpha-$ hydroxylation was found to be $0.493 \pm 0.027 \mathrm{nmol} / \mathrm{min} / \mathrm{mg}$. The $\left\{{ }^{3} \mathrm{H}\right\}-$ pregnenolone concentration was $5.0 \mu \mathrm{M}$.

There is no consistent change in the content of cytochrome P-450/ milligram microsomal protein with ACTH stimulation. The P-450 content was determined by the method of Omura and Sato. A representative cytochrome P-450 absorbence difference spectrum recording is shown in Figure 9. Although the specific activity (nmol/mg) of cytochrome P-450 


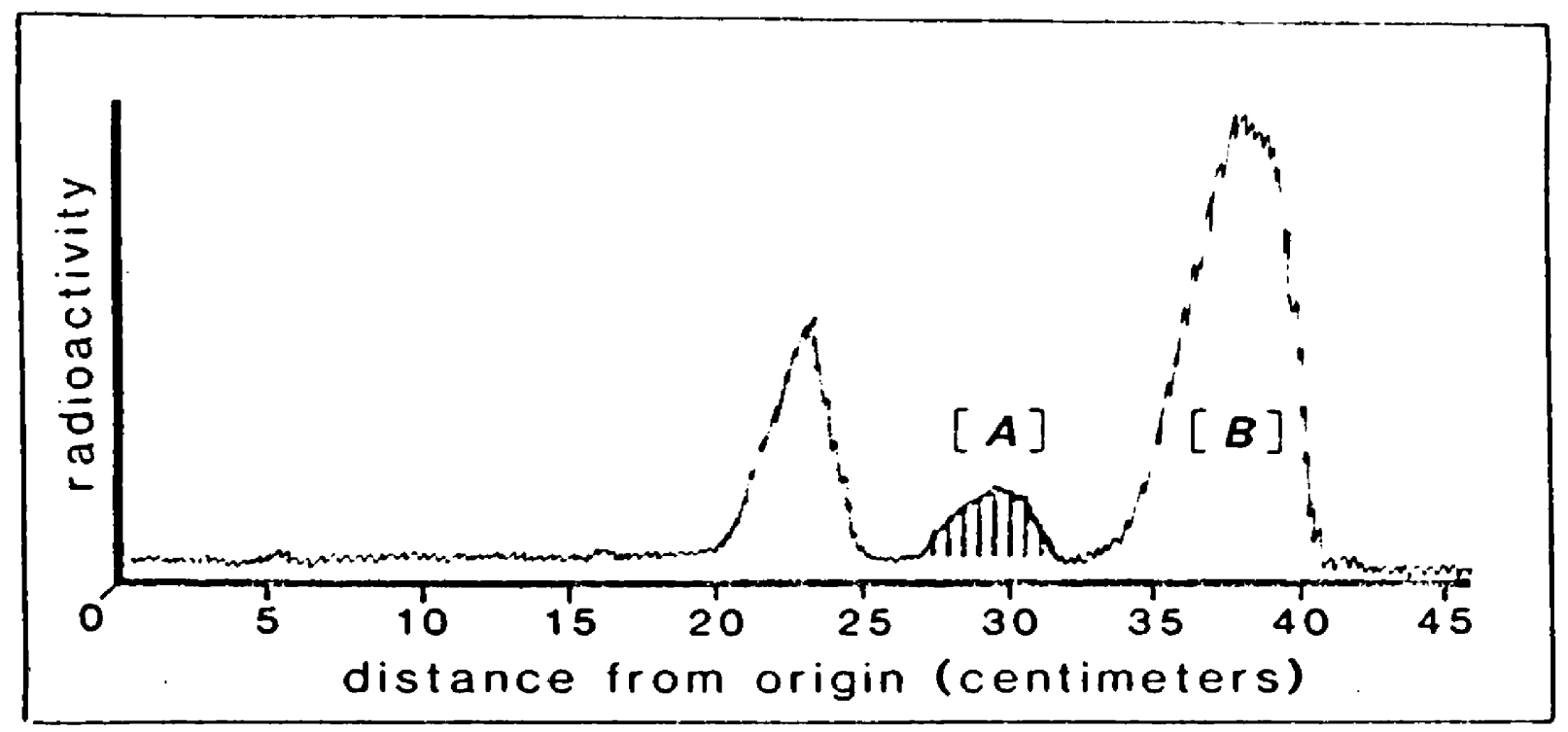

Figure 7. Radiochromatogram Tracing of a Typical Initial Paper Chromatographic Separation of $17 \alpha$-Hydroxypregnenolone from Substrate and other products. The locations of the brackets show the location of $50 \mu \mathrm{g}$ each of two non-radioactive internal standards $17 \alpha$-hydroxyprogesterone, A and progesterone, B. This tracing is from experiment 3 , four minute incubation flask, four day ACTH stimulated. 


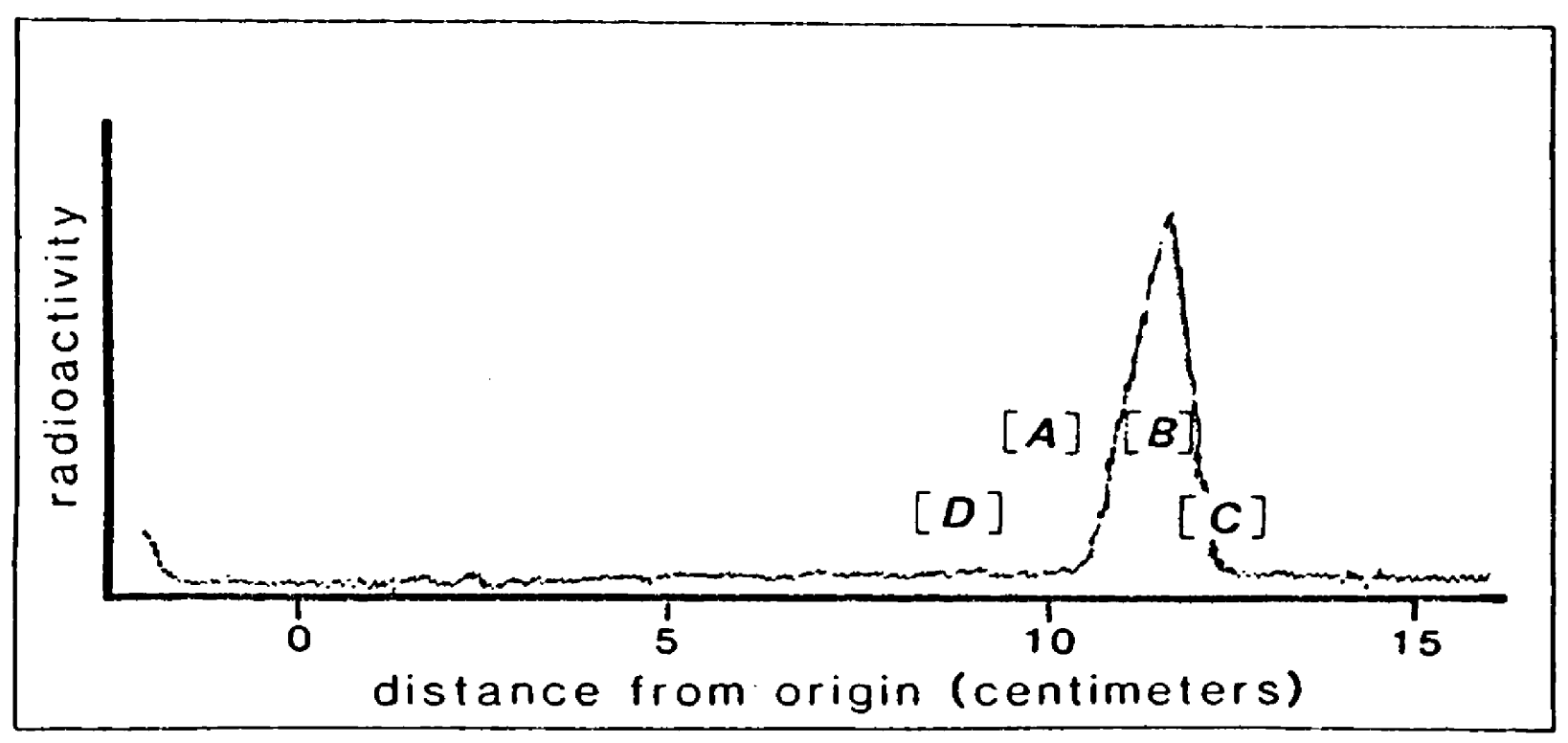

Figure 8. Radiochromatogram Tracing of a Typical Silica Gel Thin Layer Chromatographic Purification of $17 \alpha$-Hydroxy- $\left\{{ }^{3} \mathrm{H}\right\}$ - pregnenolone Isolated From Initial Paper Chromatographic Separation. The brackets marked $A$ and $B$ indicate the location of 21-hydroxypregnenolone and $17 \alpha$-hydroxypregnenolone chromatographed on a lane adjacent to the sample and visualized with sulfuric acid:ethanol $(1: 1)$ spray. The locations of the brackets marked $C$ and $D$ indi-

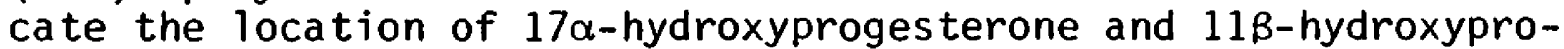
gesterone which were added to the sample prior to chromatography. Tracing is from experiment 2, four minute incubation flask, four day ACTH stimulated. 


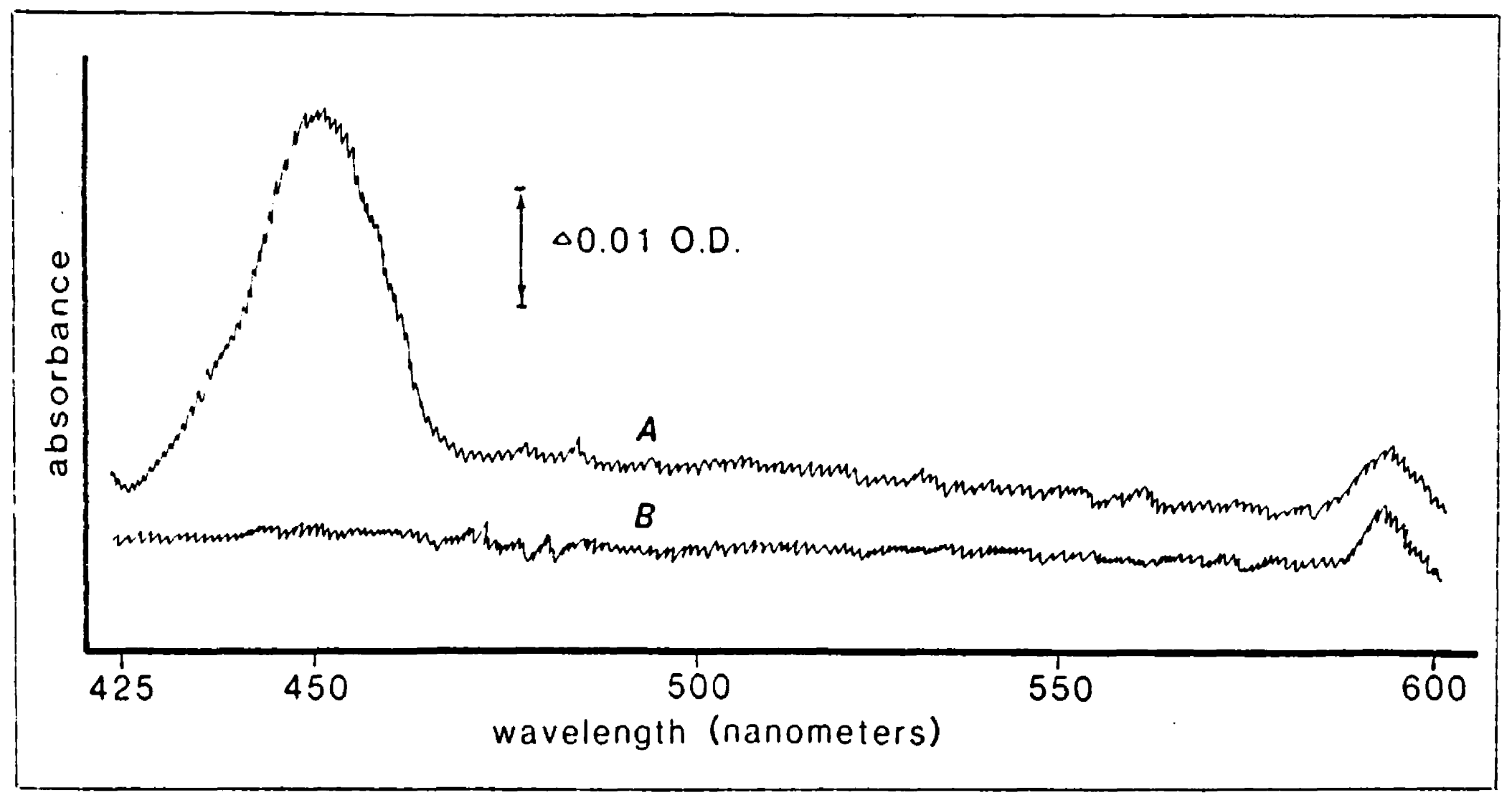

Figure 9. Representative Cytochrome P-450 Difference Spectra. The letters A and B represent the microsome suspension reduced with sodium thiosulfite $(B)$ and the reduced microsome suspension with carbon monoxide bound to the cytochrome $\mathrm{P}-450$ read against the same microsome suspension reduced with sodium thiosulfite. This scan is from experiment three, four day ACTH stimulation. 
does not increase (see Table 6), the total content generally does, especially with longer stimulation. As can be seen in Table 7, a pattern of total increase of P-450 occurs in the two, four and six day ACTH stimulated adrenals. Experiment 3 is an exception to this observation. Sodium dodecyl sulfate polyacrylamide gel electrophoresis (SDSPAGE) of adrenal microsomes from control and ACTH-stimulated rabbits resulted in patterns of protein bands that show differences. Optical measurements of gels stained for protein were recorded on scans as shown in Figure 10. The stippled areas were found to display the only major reproducible differences between control and ACTH-stimulated samples. These protein bands with molecular weights of $61,000 \mathrm{D}$ for band one, 58,000 $\mathrm{D}$ for band two and 53,000 D for band three were subsequently scanned by expanded recording methods to enhance resolution and sensitivity. These protein bands are in the molecular weight range of cytochrome $P-450$.

SDS-PAGE electrophoretic patterns were obtained for two, four and six day ACTH stimulated and control rabbit adrenal microsomes. Electrophoretogram scans of typical patterns of the three major bands from the various multiday stimulations are shown in Figure 11 . Control patterns shown in Figure 11 are from representative four and six day nonstimulated microsome samples. A representative two day control sample showed no resolution between peaks two and three.

Three patterns of change can be seen with the length of the multiday stimulations. Peak 1,61,000 D, of the four day ACTH stimulation is larger, while the two and six day stimulations are smaller, relative to control samples in adjacent lanes of the same gel. The changes in peak 
Table 5.

Increase in $17 \alpha$-Hydroxylation Due to $A C T H$

\begin{tabular}{llcc}
$\begin{array}{l}\text { Exp. } \\
\text { No. }\end{array}$ & $\begin{array}{l}\text { Days } \\
\text { Stim }\end{array}$ & $\frac{\mathrm{nmol} \text { PRODUCT }}{\mathrm{min} \cdot \mathrm{mg}}$ & $\frac{\mathrm{nmol} \text { PRODUCT }}{\mathrm{min} \cdot \mathrm{nmol} P-450}$ \\
\hline 1 & 2 & $0.342 \pm 0.040$ & $0.266 \pm 0.033$ \\
2 & 4 & $0.516 \pm 0.121$ & $0.415 \pm 0.098$ \\
3 & 4 & $0.410 \pm 0.074$ & $0.420 \pm 0.073$ \\
4 & 6 & $0.362 \pm 0.028$ & $0.310 \pm 0.022$ \\
\hline
\end{tabular}

Table 6.

Cytochrome P-450 Content of Adrenal Microsomes Isolated From Control and ACTH-Stimulated Rabbits

\begin{tabular}{|c|c|c|c|c|}
\hline \multirow{2}{*}{$\begin{array}{l}\text { Exp. } \\
\text { No. }\end{array}$} & \multirow{2}{*}{$\begin{array}{l}\text { Days } \\
\text { Stim }\end{array}$} & \multicolumn{2}{|c|}{ nmole $\mathrm{P}-450 / \mathrm{mg}$ protein } & \multirow{2}{*}{$\frac{\text { ACTH }}{\text { CONTROL }}$} \\
\hline & & ACTH & CONTROL & \\
\hline 1 & 2 & 1.28 & 1.25 & 1.024 \\
\hline 2 & 4 & 1.24 & $1.24^{\star}$ & 1.000 \\
\hline 3 & 4 & 1.00 & 1.13 & 0.885 \\
\hline 4 & 6 & 1.19 & 1.31 & 0.908 \\
\hline
\end{tabular}

* Due to technical difficulties, the cytochrome P-450 content of exp. 2 control could not be determined. The value of $1.24 \mathrm{nmol}$ was averaged from all other control values 
Table 7.

Total Adrenal Microsomal Cytochrome P-450 Content. \#

\begin{tabular}{ccccc}
$\begin{array}{l}\text { Exp. } \\
\text { No. }\end{array}$ & $\begin{array}{l}\text { Days } \\
\text { Stim }\end{array}$ & \multicolumn{2}{c}{ nmol/Adrenal Pair } & ACTH \\
\hline 1 & 2 & 0.614 & 0.553 & CONTROL \\
2 & 4 & 0.524 & $0.388^{*}$ & 1.11 \\
3 & 4 & 0.575 & 0.627 & 1.35 \\
4 & 6 & 0.696 & 0.367 & 0.92 \\
\hline
\end{tabular}

* Due to technical difficulties, the cytochrome P-450 content of experiment 2 control could not be determined. The value 0.388 was calculated from the average of the other control values.

\# Average of six pairs. 


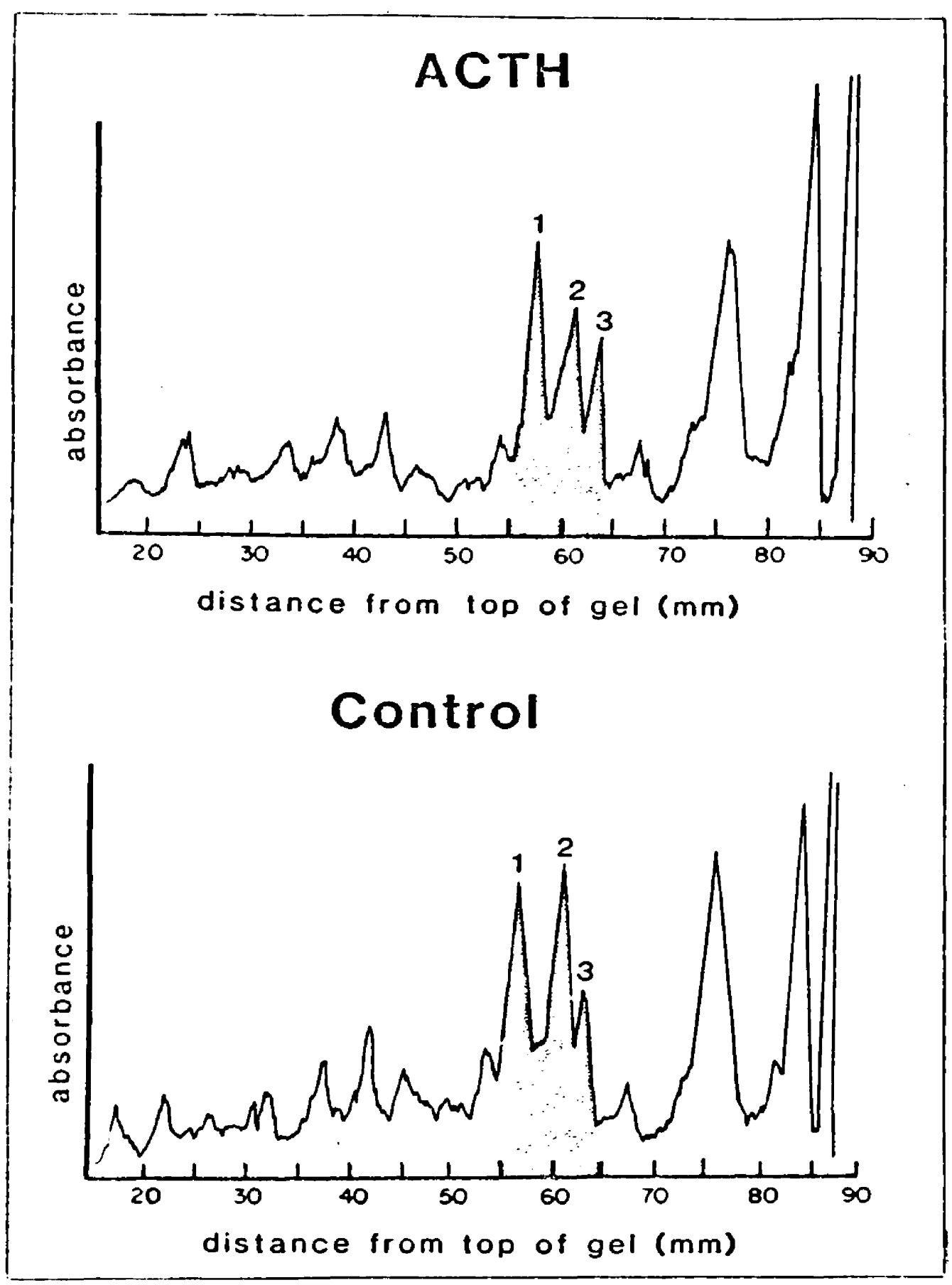

Figure 10. Electrophoretogram Scans of Typical SDS-PAGE Separations of Adrenal Microsomal Proteins. Shown are four day ACTH-stimulated and control samples. Methods of SDSPAGE are discussed in Experimental Methods. 


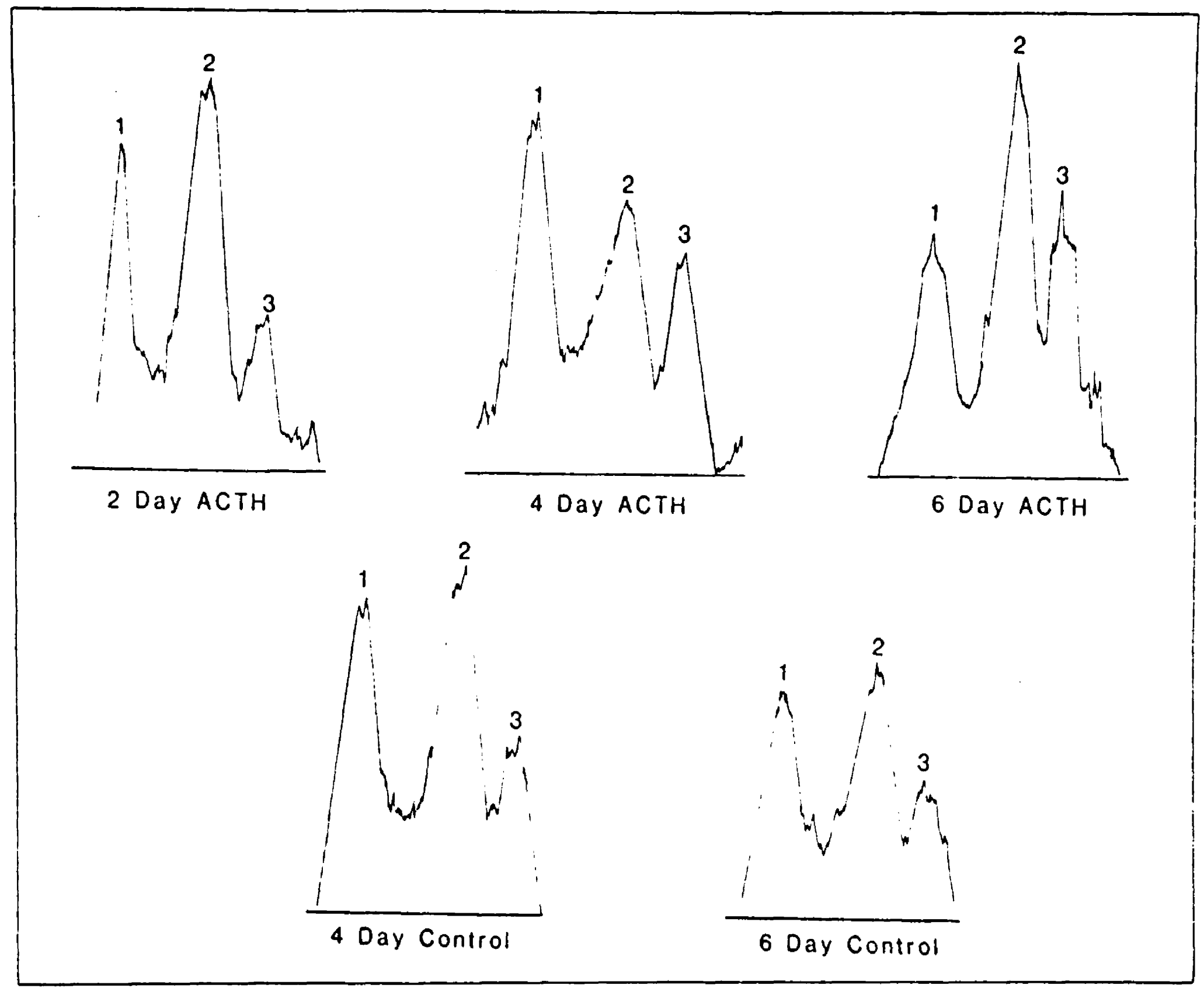

Figure 11. Electrophoretogram Scans of Typical Protein Patterns of the Major Bands from Various Multi-day Stimulations as Compared with Control. Molecular weights of the bands are: $61,000 \mathrm{D}$, band $1 ; 58,000 \mathrm{D}$, band 2 and $53,000 \mathrm{D}$, band 3 . 
two were variable with the length of stimulation. Peak three, 53,000 D, was found to increase $31.1 \%$ in two day (relative to 4 day control on the same ge1; assuming control patterns are unchanged from prep to prep), $27.2 \%$ in four day and $61.0 \%$ in six day ACTH stimulated microsomes as compared to controls (see Table 8 ). Figure 12 is a photograph of a typical 4 day ACTH stimulated microsome electrophoretic pattern as compared to control microsome, guinea pig microsome and marker proteins.

Specific staining for heme on SDS-PAGE gels using TMBZ showed the $61,000 \mathrm{D}$ band to be the major heme-containing band with minor staining in the 58,000 and $53,000 \mathrm{D}$ bands. Figure $13 \mathrm{~A}$ shows a TMBZ stain of a gel with four day samples and guinea pig samples. The same gel was then stained for protein (Figure $13 \mathrm{~B}$ ). The 53,000 D band corresponds to cytochrome $\mathrm{P}-450$ possessing $17 \alpha$-hydroxylase activity in other investigators' work. The lack of a strong 53,000 $\mathrm{D}$ heme stain may be due to the sensitivity of the procedure used. The 61,000 D band that was found to stain heavily for heme in this project may be cytochrome P-450's associated with other microsomal hydroxylases.

A slight amount of protein stain in ACTH samples was evident at about 45,000 D. This finding was not always reproducible, but it did occur. It can be seen in Figure 12 and seen as a shoulder at $73 \mathrm{~mm}$ migration in Figure 10.

The guinea pig adrenal microsome electrophoretic patterns showed a group of protein bands ranging from 48,000 D to 54,000 D. This area stained heavily for heme. 
Table 8.

SDS-PAGE Peak Areas of Major Bands from 2, 4 and 6 day ACTH stimulated and Control Rabbit Adrenal Microsomes.

\begin{tabular}{lcccccc} 
Days & \multicolumn{2}{c}{$61,000 \mathrm{D}$} & \multicolumn{2}{c}{$58,000 \mathrm{D}$} & \multicolumn{2}{c}{$53,000 \mathrm{D}$} \\
Stim & ACTH & CONTROL & ACTH & CONTROL & ACTH & CONTROL \\
\hline 2 & $29.1 \pm 0.8$ & $35.9 \pm \#$ & $49.9 \pm 7.8$ & $26.2 \pm \#$ & $17.3 \pm 1.5$ & $13.2 \pm \#$ \\
& $n=2$ & $n=1$ & $n=2$ & $n=1$ & $n=2$ & $n=1$ \\
4 & $28.2 \pm 1.0$ & $21.1 \pm 2.8$ & $33.2 \pm 8.0$ & $30.4 \pm 5.9$ & $19.6 \pm 3.7$ & $15.4 \pm 2.4$ \\
& $n=2$ & $n=4$ & $n=4$ & $n=4$ & $n=4$ & $n=4$ \\
6 & $33.6 \pm 0.6$ & $42.4 \pm 1.2$ & $57.8 \pm 3.2$ & $96.3 \pm 5.3$ & $30.1 \pm 4.8$ & $18.7 \pm 6.2$ \\
& $n=2$ & $n=2$ & $n=2$ & $n=2$ & $n=2$ & $n=2$ \\
& & & & & &
\end{tabular}

$n$ equals the number of sample wells calculated for the area with the corrections mentioned in the Experimental Methods section.

units are arbitrary

\# four-day control adjacent to two-day ACTH on same ger. 


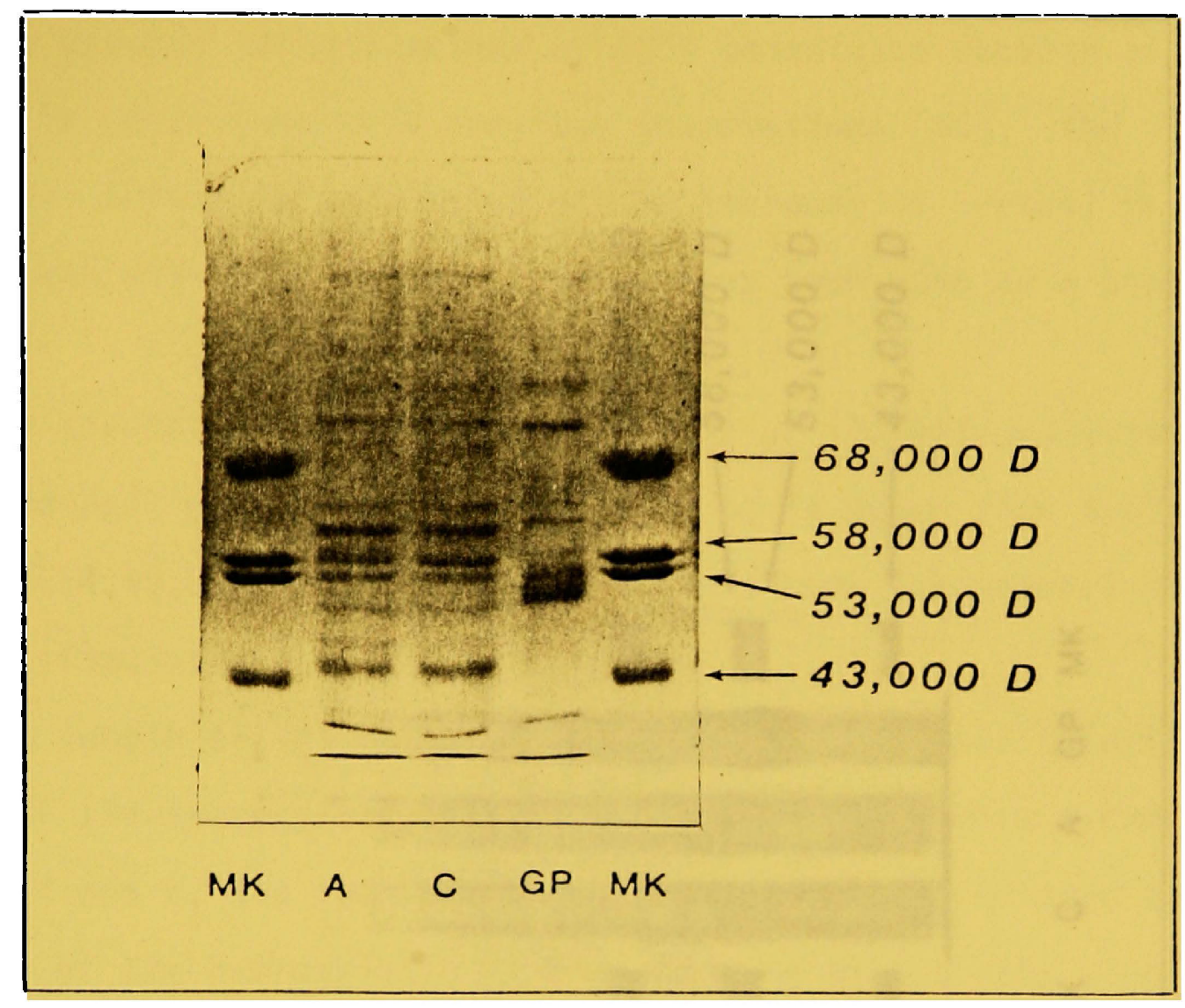

Figure 12. Photograph of an SDS-PAGE Gel Stained for Protein Content. Control (C), ACTH-stimulated (A), guinea pig (GP) and marker protein (MK) samples are shown. Marker proteins are bovine serum albumin $(68,000 \mathrm{D})$, catalase $(58,000 \mathrm{D})$, glutamate dehydrogenase $(53,000 \mathrm{D})$ and ovalbumin $(43,000 \mathrm{D})$. Four day, experiment two. 


\section{A. TMBZ}

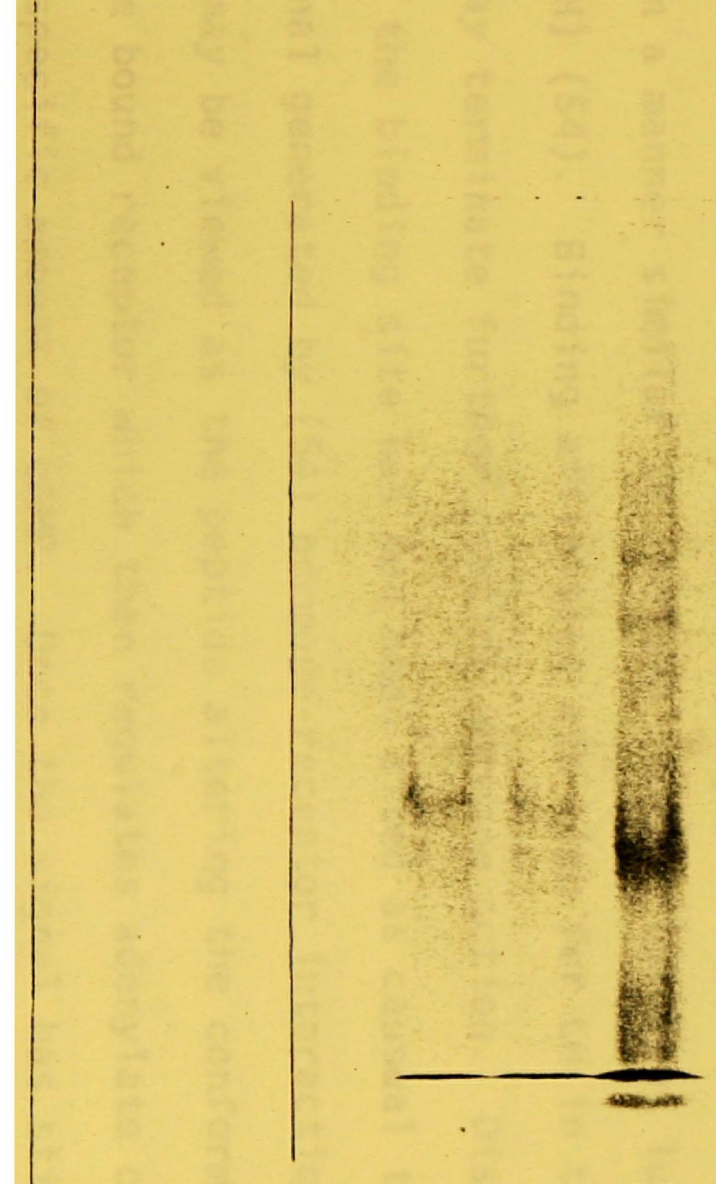

C $A$ GP

\section{B. PROTEIN}

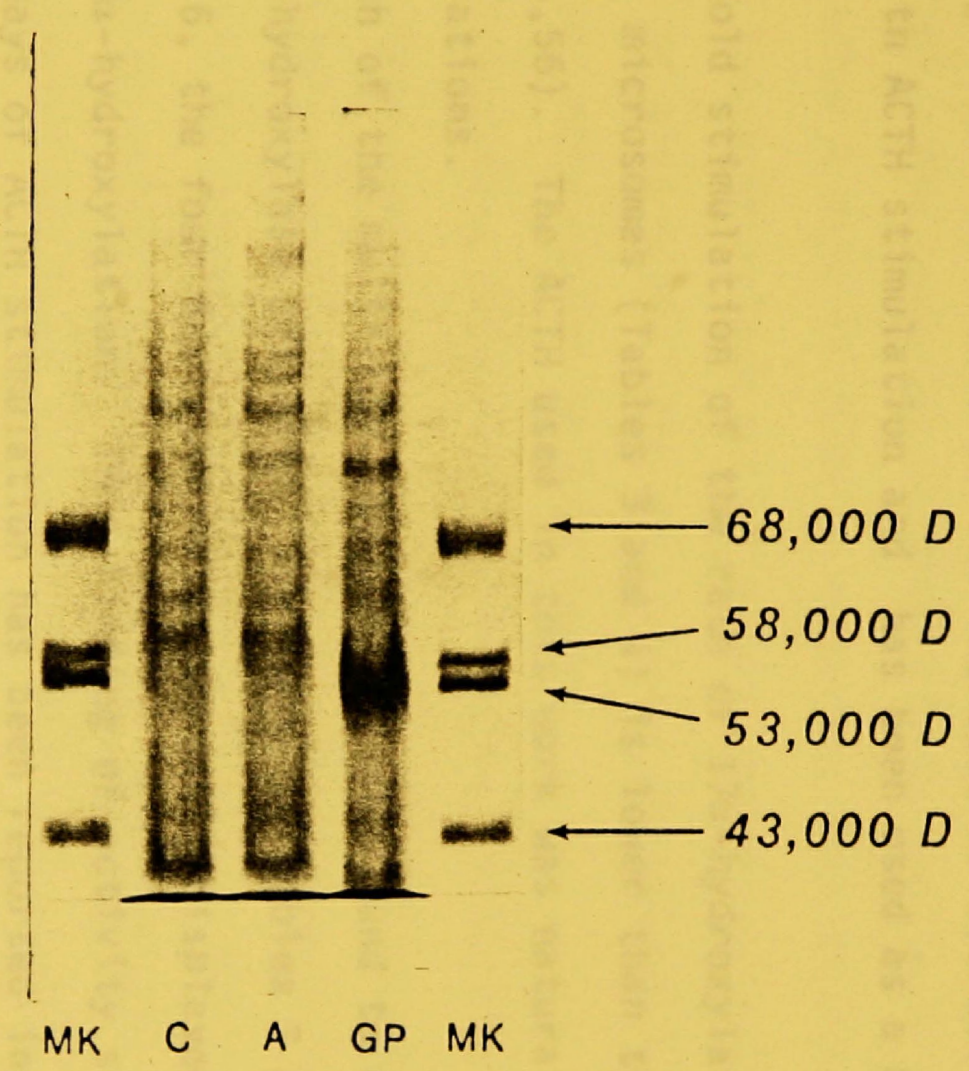

Figure 13. Photographs of SDS-PAGE gels stained with (A) TMBZ and (B) Coomassie brilliant blue. Control (C), ACTH-stimulated (A), guinea pig (GP) and marker protein (MK) samples are shown. Marker proteins are bovine serum albumin $(68,000 \mathrm{D})$, catalase $(58,000 \mathrm{D})$, glutamate dehydrogenase $(53,000 \mathrm{D})$ and ovalbumin $(43,000 \mathrm{D})$. Four day stimulation, experiment 3. 


\section{DISCUSSION}

The greater adrenal weight of ACTH stimulated rabbits as shown in Table 2 is consistent with previous observations (56). The increase in adrenal weight is indicative of the increase of overall protein synthesis seen with ACTH stimulation and has been used as a bioassay for ACTH .

The six-fold stimulation of the rate of $17 \alpha$-hydroxylation in rabbit adrenal microsomes (Tables 3 and 4 ) is lower than that reported earlier $(24,43,56)$. The ACTH used in this work was natural porcine for all stimulations.

The length of the multi-day stimulation was found to effect the degree of $17 \alpha$-hydroxylase activity. As shown in Tables 3 and 4 and Figures 4 and 6 , the four day stimulated adrenals displayed the largest rate of $17 \alpha$-hydroxylation. This finding of activity sloping off after 3 to 4 days of ACTH stimulation has been reported in the literature (43). The reason for the decrease of $17 \alpha$-hydroxylase after 4 days of ACTH stimulation is uncertain. ACTH receptor regulation may occur in a manner similar to another protein hormone, luteinizing hormone (LH) (54). Binding affinities are high for $L H$ in the Leydig cells which may terminate further peptide hormone action. Dissociations of LH from the binding site has not been cited as causual termination of the signal generated by (54) hormone-receptor interactions. The signal may be viewed as the peptide altering the conformation of the membrane bound receptor which then regulates adenylate cyclase to produce a specific amount of CAMP. Once the signal has stimulated an 
amount of CAMP production, the activity of adenylate cyclase slopes off, the receptor degrades with the bound hormone and the proteins and lipids are metabolized. This has been termed "desensitization of adenylate cyclase and target-cell responses after initial hormonal stimulation" (54). New receptor is then synthesized within the life of the cell. After 4 days of ACTH stimulation, the decrease in ACTH stimulation of $17 \alpha$-hydroxylase activity may be seen as a lack of fresh receptors able to bind ACTH. The possibility of anti-ACTH antibody formation towards ACTH cannot be overlooked.

Deoxycorticosterone (DOC) was usually found as a side product in the $17 \alpha$-hydroxylase assays. This was always a bit of a surprise since

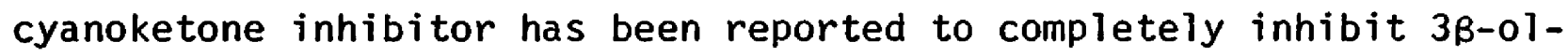
dehydrogenase at the concentration used (25). Also, NAD is a required cofactor for 3ß-ol-dehydrogenase but was not added to the incubation media. This finding has been reported in previous studies (25). Apparently, in order to totally limit DOC formation, the microsomes would need to be thoroughly freed of bound NAD and 3B-ol-dehydrogenase inhibited more completely. This could have deleterious effects on the microsomal membranes and $17 \alpha$-hydroxylase activity. So further washing or using different inhibitors should be undertaken with the greatest of caution.

In an effort to determine what chemical changes in protein composition occur to facilitate the increased $17 \alpha$-hydroxylase activity during ACTH stimulation, SDS-PAGE with protein and specific heme staining methods were employed as analytical tools. As discussed in the Statement of Problem section, an increase of a protein band containing a 
cytochrome P-450 could give insight into this mechanism. As shown in Figures 10, 11 and 12, and Table 8, a 53,000 D band increased in amount with the days of stimulation. The $17 \alpha$-hydroxylase activity did not parallel this increase. This band is of interest because it is of the same molecular weight as an adrenal microsomal protein that is phosphorylated during short term (i.e. 15 minutes) ACTH stimulation (21, 22). As with all phosphorylation this regulation is post-transcriptional and independent of mRNA synthesis.

Longer term ACTH stimulation of synthesis of specific protein in adrenal microsomes were reported by Guenthner, Nebert and Menard (32). Electrophoretic patterns of adrenal microsomal protein from control and hypophysectomized rats demonstrated recovery of protein bands in the hypophysectomized rats with apparent molecular weights of 53,000 D and 57,000 D with ACTH stimulation. The 57,000 D band has been correlated with aryl hydrocarbon hydroxylase (AHH) (32). The 53,000 D band has been suggested to represent 21 - and $17 \alpha$-hydroxylase activity (36). Studies by Menard (36) demonstrated 17a-hydroxylase activity and cytochrome P-450 content decreased upon administration of spironolactone, a diuretic steroid. The content of the 57,000 D protein (associated with AHH activity) appeared virtually unaffected as compared to control (36), while the $54,000 \pm 1,000 \mathrm{D}$ band decreased in concentration with the $17 \alpha$-hydroxylase activity and cytochrome $\mathrm{P}-450$ content in rat testis.

Investigators $(36,32,45)$ have termed the adrenal microsomal proteins with electrophoretic molecular weights in the 50-60,000 D range "apoproteins of cytochrome P-450."

Tetramethylbenzidine (TMBZ) staining of adrenal microsome samples 
electrophoresed as described in Experimental Procedures showed the major heme staining protein band to have a molecular weight of $61,000 \mathrm{D}$. The degree of sensitivity of the TMBZ method apparently did not allow detection of a 53,000 D heme. If a cytochrome P-450 containing 53,000 D protein is present in very low concentration after ACTH stimulation, it could be present below the detection limits of the TMBZ method. Some loss of the heme group from cytochrome P-450 during electrophores is has been reported (42) but was not accurately quantitated. These investigators found that free heme in the form of hematin could be detected in concentrations as low as $3 \mathrm{pmol} / \mathrm{gel}$.

The 48,000 D to $54,000 \mathrm{D}$ protein bands of the guinea pig adrenal microsome that stain for heme further substantiates the 53,000 D molecular weight range for cytochrome $\mathrm{P}-450$ possessing $17 \alpha$-hydroxylase activity, since $17 \alpha$-hydroxylase is present in guinea pig adrenal microsomes in the basal state. The cytochrome P-450 responsible for this activity has a molecular weight in close agreement with the 53,000 D band that was found to increase in amount in this study with ACTH stimulation.

The $61,000 \mathrm{D}$ protein that stained for heme was present at about the same concentration in both control and ACTH-stimulated adrenal microsome samples. It is possible that the $61,000 \mathrm{D}$ band is cytochrome P-450 that is associated with other microsomal hydroxylases. It has also been suggested (30) that the microsomes contain a free pool of cytochrome P-450 "earmarked" for insertion into mixed function oxidase systems.

The apparent lack of an increase of cytochrome P-450 specific 
activity with longer-term ACTH stimulation (Table 6) has previously been reported in the 1 iterature as a decrease or no change $(25,56)$. The exact role of P-450 in the increase of adrenal microsomal $17 \alpha$-hydroxylase subsequent to ACTH stimulation still needs elucidation. The difficulty may be inherent in the method of Omura and Sato. The pyridine hemochromagen method may yield a different result (55). Although the content of cytochrome P-450 per milligram microsomal protein does not increase, the total content generally does, especially with longer-term stimulation (Table 7). A pattern of total increase of cytochrome P-450 can be seen in the two, four and six day ACTH stimulated adrenals. As indicated by the general lack of increase in the $\mathrm{P}-450 / \mathrm{mg}$ microsomal protein, the increase in the total amount is probably due to the increase in adrenal weights and general proliferation of the endoplasmic reticulum.

Since multiple cytochromes are known to exist in steroidogenic microsomes (32), the preferred increase in a specific cytochrome responsible for the $17 \alpha$-hydroxylase should be accompanied by a decrease in the amount of cytochrome responsible for another hydroxylase activity. This would be expected since the specific activity of cytochrome $\mathrm{P}-450$ remains about the same and other hydroxylase activities are not sacrificed for enhanced $17 \alpha$-hydroxylase activity.

The increase seen in the 53,000 D band was reproducible from gel to ge1. This increase did not parallel the $17 \alpha$-hydroxylase activity which peaked at four days ACTH stimulation.

The 61,000 D band showed a large increase in the four day over the two and six day ACTH stimulated tissue. This cannot be visualized as an increase in a protein parallel to $17 \alpha$-hydroxylase activity since the two 
and six day stimulated tissues showed the 61,000 D band to be smaller than control.

The actual mechanism of $17 \alpha$-hydroxylation during ACTH stimulation still needs elucidation. This study shows that the differences between ACTH stimulated and control adrenal microsomes seen by SDS-PAGE are on a minute scale. There were no new bands, only increased staining intensity. Relating this finding to the original hypothesis on page 13, leads to the conclusion that a specificity protein may be playing a major role. This protein, possibly originating from enhanced post-transcriptional regulation through phosphorylation of ribosomal subunits, would enhance the binding of pregnenolone to 17a-hydroxylase which probably shares the same catalytic center, cytochrome P-450, with 21hydroxylase. The nature of this protein needs further isolation and characterization. 


\section{REFERENCES}

1. Schulster, D., Burstein, S. and Cooke, B.A., (1976), in Molecular Endocrinology of Steroid Hormones, John Wiley \& Sons, New York, NY, pp 44-64, 98-115.

2. Turner, E. and Lipner, H., (1976), in General Endocrinology, Englewood Cliffs, New Jersey, Prentice-Hall Inc., pp 291-351.

3. Bloch, K., (1965), The Biological Synthesis of Cholesterol, Science N.Y., 150 , pp 19-28.

4. Hanukoglu, I. and Jefcoate, C. (1980), Mitochondrial Cytochrome P-450 Side Chain Cleavage, J. Biol. Chem. 255, pp 3057-3061.

5. Garfinke1, D. (1958), Studies on Pig Liver Microsomes. I. Enzymic and Pigment Composition of Different Microsomal Fractions, Arch. Bioch. Bioph., 77, pp. 493-509.

6. Klingenberg, M., (1958), Pigments of Rat Liver Microsomes, Arch. Biochem. Biophys., 75, pp 376-386.

7. Omura, T. and Sato, R., (1964), The Carbon Monoxide-binding Pigment of Liver Microsomes. I. Evidence for its Hemoprotein Nature, J. Biol. Chem., 239, pp 2370-2378, (1964).

8. White, R.E., Coon, M.J., (1980), Ann. Rev. Biochem., 49, E.E. Snell ed., Annual Reviews Inc., Palo Alto, Calif., pp 315-356.

9. Hanukoglu, I., Spitsler, V., Bumpus, J., Dus, K. and Jefcoate, C., (1981), Adrenal Mitochondrial Cytochrome P-450 Side Chain Cleavage, $\mathrm{J}$. Biol. Chem., 256, pp 4321-4328.

10. Stone, D. and Hechter, 0., (1954), Studies on ACTH Action in Perfused Bovine Adrenals: The Site of Action of ACTH in Corticosteroidogenes is, Arch. Biochem. Biophys., 51, pp 457-469.

11. Seybert, D.W., Lancaster, J.R., Lambeth, J.D. and Kamin, H., (1979), Participation of the Membrane in the Side Chain Cleavage of Cholesterol, J.Biol. Chem., 254, pp 12088-12098.

12. Rothman, J.E. and Engleman, D.M., (1972), Molecular Mechanism for the Interaction of Phospholipid with Cholesterol, Nature New Biol., 237, pp 42-44.

13. Malkinson, A.M. (1975) in Hormone Action, John Wiley and Sons, Inc.

14. Peron, F.G.. and McCarthy, J.L., (1968), Corticosteroidogenes is in the Rat Adrenal Gland, in Functions of the Adrenal Cortex, v. 1, K.W. McKerns, ed. Appel ton-Century-Crofts, New York, NY, pp 261-337. 
15. Sweat, M.L. (1951), Enzymatic Synthes is of 17-hydroxycorticosterone, J. Amer. Chem. Soc., 73, p 4056.

16. Saffran, M. and Schally, A.V., (1955), In vitro Bioassay of Corticotropin, Endocrinology, 56, pp 523-532.

17. Haynes, R.C. and Berthet, L. (1957), Studies on the Mechanism of Action of the Adrenocorticotropic Hormone, J. Biol. Chem., 225, pp 115-124.

18. Gill, G.N. and Garren, L.D., (1971), Role of the Receptor in the Mechanism of Action of Adenosine $3^{\prime}: 5^{\prime}-$ cyclic monophosphate. Proc. Nat. Acad. Sci., 68, pp 786-790.

19. Brostrom, C.0., Corbin, J.D., King, C.A. and Krebs, E.G., (1971), Separation of Regulatory and Catalytic Subunits of the Cyclic $3^{\prime}: 5^{\prime}$-Adenosine Monophosphate-Dependent Protein Kinase(s) of Rabbit Skeletal Muscle, Biochem. Biophys. Res. Comm., 42, pp 187-194.

20. Sala, G.B., Hayashi, K., Catt, K.J. and DuFau, M.C., (1979), ACTH Action in Isolated Cells: The Intermediate Role of cAMP in Stimulation of Corticosterone Synthesis., J. Biol. Chem., 254, pp 3861-3865.

21. Koroscil, T. and Gallant, S., (1980), Mechanism of Action of ACTH: Role of ACTH-stimulated Phosphorylation and Dephosphorylation of Adrenal Proteins, J. Biol. Chem., 255, pp 6276-6283.

22. Koroscil, T. and Gallant, S., (1981), The Phosphorylation of Adrenal Proteins in Response to ACTH, J. Biol. Chem., 256, pp 6700-6707.

23. Fevold, H.R. (1967), Regulation of the Adrenal Cortex Secratory Pattern by ACTH, Science, 156, pp 1753-1755.

24. Fevold, H.R. and Hubert, T.D., (1969), The Pathways of Corticosteroid Biosynthesis by Homogenates of Adrenal Tissue from Rabbits Stimulated with ACTH., Biochem., 8, pp 3433-3439.

25. Fevold, H.R., Wilson, P.L. and Slanina, S.M., (1978), ACTHstimulated Rabbit Adrenal 17 $\alpha$-Hydroxylase: Kinetic Properties and a Comparison with those of $3 \beta$-Hydroxysteroid Dehydrogenase, J. Steroid Biochem., 9, pp 1033-1041.

26. Kass, E.H., Hechter, 0., Macchi, I.A. and Mou T.W., (1954), Changes in Patterns of Secretion of Corticosteroids in Rabbits After Prolonged Treatment with ACTH. Proc. Soc. exp. Biol. Med., 85, pp. 583-587. 
27. Weliky, I. and Engel, L.L., (1963), Metabolism of Progesterone $-4-{ }^{4} \mathrm{C}$ - and Pregnenolone-7 $-{ }^{3} \mathrm{H}$ by Human Adrena 1 Tissue. Formation of $17 \alpha$-Hydroxyprogesterone $-{ }^{14} \mathrm{C}$-corticosterone and Cortisol $-{ }^{14} \mathrm{C}-{ }^{3} \mathrm{H}$. J. Biol. Chem. 238, pp 1302-1307.

28. Slaga, T.J. and Krum, A.A., (1973), Modification of Rabbit Adrenal Steroid Biosynthes is by Prolonged ACTH Administration. Endocrinology, 93, pp 517-526.

29. McMurtry, R. and Hagerman, D., (1972), Co inhibition of Progesterone 17-Hydroxylation and Side Cha in Cleavage Catalyzed by Rat Testis Microsomes. Steroids Lipids Res., 3, pp 8-13.

30. Purvis, J.L., Canick, J.A., Mason, J.I., Estabrook, R.W. and McCarthy, J.L., (1973), Lifetime of Adrenal Cytochrome P-450 as Influenced by ACTH., Ann. N.Y. Acad. of Sci., 212, pp 319-343.

31. Purvis, J.L., Canick, J.A., Latif, S.A., Rosenbaum, J.H., Hologgitas, J. and Menard, R.H., (1973), Lifetime of Microsomal Cytochrome P-450 and Steroidogenic Enzymes in Rat Testis as Influenced by Human Chorionic Gonadotrophin., Arch. Biochem. Biophys., 159, pp 39-49.

32. Guenthner, T., Nebert, D., Menard, R., (1978), Microsoma 7 Ary 1 Hydrocarbon Hydroxylase in Rat Adrenal Regulation by ACTH, but not Polycyclic Hydrocarbons. Mol. Pharmacol., 15, pp 719-728.

33. Haugen, D.A., van der Hoeven, T.A., Coon, M.J., (1975), Purified Liver Microsomal Cytochrome P-450. Separation and Characterization of Multiple Forms., J. Biol. Chem., 250, pp 3567-3570.

34. Guengerich, F.P., (1977), Separation and Purification of Multiple Forms of Microsomal Cytochrome P-450: Activities of Different Forms of Cytochrome P-450 Towards Several Compounds of Environmental Interest. J.Biol. Chem., 252, pp 3970-3979.

35. Miwa, G.T., West. S.B., Huang, M-T, Lu, A.Y.H., (1979), Studies on the Association of Cytochrome P-450 and NADPH-Cytochrome C Reductase during Catalysis in a Reconstituted Hydroxylating System., J. Biol. Chem., 254 (13), pp 5695-5700.

36. Menard, R., Guenthner, T., Kon, H., Gillette, J., (1979), Studies on the Destruction of Adrenal and Testicular Cytochrome P-450 by Spironolactone. J. Biol. Chem., 254 (5), pp 1726-1733. 
37. Lu, A.Y.H. and Coon, M.J., (1968), Role of Hemoprotein P-450 in Fatty Acid w-Hydroxylation in a Soluble Enzyme System from Liver Microsomes, J. Biol. Chem., 243, pp 1331-1332.

38. Lowry, O.H., Rosebrough, N.J., Farr, A.L. and Randall, R.J., (1951), Protein Measurement with the Fol in Phenol Reagent, J. Biol. Chem., 193, pp 265-275.

39. Zaffaroni, A., (1953), Micromethods for the Analysis of Adrenocortical Steroids, Rec. Prog. Horm. Res., 8, pp 51-86.

40. Laemmli, U.K. (1970), Cleavage of Structural Proteins during the Assembly of the Head of Bacteriophage T4, Nature (London), 227, pp 680-685.

41. Studier, T.W., (1973), Analys is of Bacteriophage T7 Early RNA ${ }^{5}$ and Proteins on Slab Gels, J. Mol. Biol., 79, pp 237-248.

42. Thomas, P.E., Ryan, D. and Levin, W., (1976), An Improved Staining Procedure for the Detection of the Peroxidase Activity of Cytochrome P-450 on Sodium Dodecyl Sulfate Polyacrylamide Gels, Ana 1. Biochem., 75, pp 168-176.

43. Fevold, H.R. and Hubert, T.D., (1968), Synthetic $\beta^{1-24}$ - Corticotropin stimulation of Cortisol Biosynthes is by Rabbit Adrenal Tissue, Steroids, 12, pp 697-704.

44. Wise, E.M. Jr. and Ball, E.G., (1964), Malic Enzyme and Lipogenes is, Proc. Nat. Acad. Sci. USA, 52, pp 1255-1263.

45. McKerns, K.W., (1962), Significance of the Pentose Shunt Dehydrogenases in Corticosteroid Biosynthesis, Biochem, Biophys. Acta, 65, pp 536-537.

46. Bumpus, J.A., Obidoa, 0. and Dus, K.M., (1980), Purification and Characterization of Steroid Metabolizing Cytochrome P-450 Dependent Mixed Function 0xidase System from Bovine Adrenocortical Microsomes, in Drug Oxidations and Chemical Carcinogenesis, v. 1, pp 203-206.

47. Ryan, K. J. and Engel, L.L., (1956), Steroid 21-Hydroxylation by Adrenal Microsomes and Reduced TPN, J. Amer. Chem. Soc., 28, pp 2654-2655.

48. Krum, A.A. and Glenn, R.E., (1965), Adrenal Steroid Secretion in Rabbits following Prolonged ACTH Administration, Proc. Soc. Exptl. Biol. Med., 118, pp. 255-258.

49. Welton, A.F., 0'Neal, F.0., Chaney, L.C. and Aust, S.D., (1975), Multiplicity of Cytochrome P-450 Hemoproteins in Rat Liver Microsomes, J. Biol. Chem., 250 (14), pp 5631-5639. 
50. Welton, A.F. and Aust, S., (1974), Multiplicity of Cytochrome P-450 Hemoproteins in Rat Liver Microsomes, Bioch. Bioph. Res. Comm., 56 (4), pp 898-906.

51. Betz, G., Tsai, P. and Weakley, R., (1976), Heterogeneity of Cytochrome P-450 in Rat Testis Microsomes, J. Biol. Chem., 251 (9), pp 2839-2841.

52. Hal1, P., Nakajin, S., Shively, J. and Yaun, P-M., (1981), Microsomal Cytochrome P-450 from Neonatal Pig Testis, Biochem., 20, pp 4037-4042.

53. Takagi, Y., Shikita, M. and Hall, P.F., (1975), The Active form of Cytochrome P-450 from Bovine Adrenocortical Mitochondria, J. Biol. Chem., 250, pp 8445-8448.

54. Catt, K.J., Harwood, J.P., Clayton, R.N., Davies, T.F., Chan, V., Katikineni, M., Nozu, K. and Dufau, M.L., (1980), Regulation of Peptide Hormone Receptors and Gonadal Steroidogenesis, in Recent Progress in Hormone Research, 36, pp 557-622.

55. Falk, J.E., (1964), In Porphyrins and Metalloporphyrins, Elsevier, Amsterdam.

56. Sranina, S.M. and Fevold, H.R., (1982), The Enzyme Specificity of ACTH Stimulation of Rabbit Adrenal Microsomal 17 $\alpha$-Hydroxylase Activity, J. Steroid. Biochem., 16, pp 93-99. 